\title{
Culture Environment Regulates Amino Acid Turnover and Glucose Utilisation in Human ES Cells
}

Joy Rathjen ${ }^{1,2}$, Christine Yeo ${ }^{1}$, Charlotte Yap ${ }^{1}$, Boon Siang Nicholas Tan ${ }^{1}$, Peter D. Rathjen $^{1,2}$ and David K. Gardner ${ }^{1 *}$

${ }^{1}$ Department of Zoology, University of Melbourne, 3010, Victoria, Australia, ${ }^{2}$ Menzies Research Institute Tasmania, University of Tasmania, 17 Liverpool Street, Hobart, 7000, Tasmania, Australia.

\footnotetext{
*Address correspondence to Prof. David Gardner, Department of Zoology, University of Melbourne, Parkville, VIC 3010, Australia +613 8344 6259. Email:

david.gardner@unimelb.edu.au
}

Running title: Culture environment regulates human ES cells

Keywords: human embryonic stem cells, metabolomics, amino acid turnover, carbohydrate use, pluripotency 
1 Abstract

2 Human embryonic stem (ES) cells have been proposed as a renewable source of

3 pluripotent cells that can be differentiated into various cell types for use in research, drug

4 discovery and in the emerging area of regenerative medicine. Exploitation of this

5 potential will require the development of ES cell culture conditions that promote

6 pluripotency and a normal cell metabolism, and quality control parameters that measure

7 these outcomes. There is, however, relatively little known about the metabolism of

8 pluripotent cells or the impact of culture environment and differentiation on their

9 metabolic pathways. We have examined the effect of two commonly used medium

10 supplements and cell differentiation on metabolic indicators in human ES cells. Medium

11 modifications and differentiation were compared in a chemically defined and feeder

12 independent culture system. Adding serum increased glucose utilisation and altered

13 amino acid turnover by the cells, as well as inducing a small proportion of the cells to

14 differentiate. Cell differentiation could be mitigated by inhibiting p38 MAPK activity.

15 The addition of Knock Out Serum Replacer ${ }^{\circledR}$ also increased glucose uptake and changed

16 amino acid turnover by the cells. These changes were distinct from those induced by

17 serum and occurred in the absence of detectable differentiation. Induction of

18 differentiation by BMP4, in contrast, did not alter metabolite turnover. Deviations from

19 metabolite turnover by ES cells in fully defined medium demonstrated that culture

20 environment can alter metabolite use. The challenge remains to understand the impact of

21 metabolic changes on long-term cell maintenance and the functionality of derived cell

22 populations. 


\section{Introduction}

24 Pluripotent cell lines derived from the human blastocyst, human embryonic stem (ES)

25 cells, were first described in 1998 (Thomson et al. 1998; Reubinoff et al. 2000). In the

26 intervening years the isolation of more than 200 individual human ES cell lines has been

27 reported (reviewed in (Adewumi et al. 2007)). Despite the varied genetic background of

28 these isolates, and the diversity of clinics and laboratory conditions involved in their

29 isolation, these cells show a remarkable consistency with regards to pluripotent cell

30 marker expression (Adewumi et al. 2007). They retain a broad differentiation potential in

31 culture, capable of generating cell populations consistent with derivatives of the three

32 primary germ lineages and the extraembryonic endoderm. The cells can be propagated

33 indefinitely while maintaining a normal karyotype and express genetic markers and cell

34 surface antigens correlated with pluripotency, including OCT4, NANOG, TDGF, GDF,

35 DNMT3B, FGF4, GCTM2 and TRA1-60/TRA1-81 (Adewumi et al. 2007). To date, the

36 evaluation of human ES cell lines has focused on assessing parameters that are associated

37 with cell function, or pluripotency. In contrast, little emphasis has been placed on

38 characterizing the physiology of these cells. Given that appropriately regulated

39 metabolism is fundamental to cell function and viability, it is paramount that a greater

40 understanding of metabolic events that occur during stem cell derivation, culture and

41 differentiation is developed. Application of this knowledge will underpin the

42 development of propagation media and protocols that ensure maintenance of cell state

43 and cell physiology. Cell physiology markers are not currently employed for the appraisal

44 of human ES cells in culture or in the development of human ES cell culture medium. 
45 The physiology of the early embryo, from which ES cells are routinely derived, has been

46 extensively characterized. Perturbation of the metabolism of the preimplantation embryo

47 significantly impairs subsequent embryo implantation and development (Lane and

48 Gardner 1996; Gardner 1998). Embryonic metabolism is sensitive to the composition of

49 culture medium. Serum, a common addition to culture media, has been shown to damage

50 blastomere ultrastructure, specifically affecting mitochondrial state and function

51 (Thompson et al. 1995). As a consequence, oxidative function is compromised, gene

52 expression and imprinting affected and embryo development impaired (Khosla et al.

53 2001). Subsequent fetal development in laboratory and domestic animals is associated

54 with compromised outcomes, demonstrating that altered physiology at the

55 preimplantation embryo stage, induced by the culture medium, has significant

56 downstream effects (Thompson et al. 1995; Gardner 1998; Lane and Gardner 2005).

57 Early alterations in physiology likely impact later developmental through interaction with

58 the epigenetic programming that occurs at this stage in development and causing the

59 establishment of epigenetic marks that impinge on later life (Donohoe and Bultman

60 2012). The development of culture media designed to maintain normal embryo

61 physiology and function, coupled with the development of metabolic markers of

62 embryonic viability (Gardner 1998; Sakkas and Gardner 2005; Gardner 2011) has

63 resulted in improvements in embryo quality in culture and concomitant improvements in

64 outcomes from assisted reproductive technologies in laboratory and domestic animals and

65 in humans (Oddens 2006).

66 Understanding the environmental requirements for the optimal maintenance of human ES

67 cells in culture will require knowledge not only of the signaling pathways that regulate 
68 pluripotency and differentiation but also, and of equal significance, of the specific

69 nutrient requirements of the cell and how the metabolome is affected by different

70 environmental conditions and states of differentiation. One of the limitations of

71 characterizing human ES cell physiology is the diversity of medium and supplements that

72 are routinely used in the culture of these cells coupled with a lack of systematic

73 assessment of how human ES cells respond to the culture environment. Here we

74 characterize glucose use and amino acid turnover in human ES cells in culture; both of

75 these parameters have been used to assess embryo quality and can be correlated with

76 improved embryo outcome (Lane and Gardner 1996; Houghton et al. 2002; Brison et al.

77 2004; Gardner 2011; Gardner et al. 2011). The addition of serum (20\%), or Knockout

78 Serum Replacer (Knockout ${ }^{\mathrm{TM}}$ SR; Life Technologies; 20\%), to a chemically-defined

79 human ES cell culture system resulted in altered amino acid turnover, increased uptake

80 and metabolism of glucose and increased cell loss from the population. These changes

81 did not correlate with the level of pluripotency, extent of differentiation in the cultures or

82 with changes in cell proliferation. In contrast, induction of differentiation by BMP4 in

83 this system had little effect on glucose uptake and metabolism or amino acid turnover.

84 These data demonstrate that in human ES cells metabolic indicators can be affected

85 significantly by the culture environment and suggest that the cells can experience stress in

86 response to sub-optimal culture conditions. Before the full realization of the clinical and

87 commercial potential of human ES cells can be achieved the impact of altering cell

88 metabolism on viability and function needs to be understood. 
Materials and Methods

Human ES cell culture

92 The human ES cell line, MEL-2 (Australian Stem Cell Centre), was cultured in mTeSR1

93 medium (STEMCELL Technologies) (Ludwig et al. 2006a; Ludwig et al. 2006b), on

94 human ES cell-qualified Matrigel ${ }^{\mathrm{TM}}$ (BD Biosciences), as per the manufacturer's

95 instructions. Cells were passaged every 7 days using Dispase (STEMCELL

96 Technologies) at $37^{\circ} \mathrm{C}$. Cell clumps were resuspended in mTeSR 1 medium and plated at

97 a ratio of 1:6 to 1:10 in 6 or 12 well cluster dishes (Falcon, Becton, Dickinson and

98 Company). Cells were cultured at $37^{\circ} \mathrm{C}$ in $5 \% \mathrm{CO}_{2}$ in ambient air in a Galaxy $\mathrm{R}$ incubator

99 (RS Biotech). Foetal calf sera (sourced from Invitrogen and Hyclone) and Knock-out

100 Serum Replacer (Knockout ${ }^{\mathrm{TM}} \mathrm{SR}$; Invitrogen ) were added after 72 hours (FCS and

101 Knockout ${ }^{\mathrm{TM}} \mathrm{SR}$ ) or 144 hours (FCS) and replaced daily until day 7, or 168 hours.

102 SB203580 (Sigma Aldrich) was added after 72 hours to a concentration of $10 \mu \mathrm{M}$; a

103 commensurate volume of diluent (DMSO) was added to controls. Medium was replaced

104 at a similar time each day. Each experiment was set up in triplicate and triplicate wells

105 were treated as a covariate in statistical analysis. On completion of cell culture and after

106 medium collection cells were incubated with TrypLE Select (Life Technologies) for 8

107 minutes at $37^{\circ} \mathrm{C}$, triturated to a single cell suspension and counted on a haemocytometer.

108 Images of human ES cells were captured on an Olympus IX50 inverted microscope.

109 Real-time Reverse Transcription-Polymerase Chain Reaction (RT-PCR)

110 Total RNA was extracted from human ES cells with an RNAqueous-4PCR Kit (Ambion)

111 according to the manufacturer's instructions. RNA was DNaseI treated (Ambion) and

112 cDNA was synthesized with M-MLV Reverse Transcriptase (Promega) and oligo(dT)

Culture environment regulates human ES cells

3 April 2013 
113 primers (Promega). Real-time PCR reactions were set up in triplicate using ABsolute

114 Blue QPCR SYBR Green Mix (Thermo Fisher Scientific) and run on an MJ research

115 thermocycler with a Chromo4 Continuous Fluorescence Detection System (MJ Research)

116 in the following sequence: $95^{\circ} \mathrm{C}$ for 15 minutes, followed by 40 cycles of denaturation at

$11795^{\circ} \mathrm{C}$ for 15 seconds, annealing at $60^{\circ} \mathrm{C}$ for 30 seconds and extension at $72^{\circ} \mathrm{C}$ for 30

118 seconds. The sequences of primers are listed in Table S1. The relative concentration of

119 each gene was normalized to $\beta$-ACTIN and analysed using Q-Gene software package

120 (Simon 2003).

\section{Analysis of metabolic activity}

122 Media, collected from human ES cells 96 or 24 hours after addition of FCS or

123 Knockout ${ }^{\mathrm{TM}}$ SR and 24 hours after the culture medium was renewed, were snap-frozen in

124 liquid nitrogen and stored at $-80^{\circ} \mathrm{C}$. Media only controls comprised media that had been

125 incubated for 24 hours at $37^{\circ} \mathrm{C}$ in a well pre-coated with Matrigel ${ }^{\mathrm{TM}}$. Nutrient

126 consumption and metabolite production rates, expressed as fmol/cell/hour, were

127 calculated using the following formula: Consumption or production rate $=\mathrm{C}_{0}-\mathrm{C}_{1} / \#$ of

128 cells $\mathrm{X} \#$ of hours where $\mathrm{C}_{0}$ is the nutrient or metabolite concentration in control media

129 and $\mathrm{C}_{1}$ is the nutrient or metabolite concentration in the experimental media. Cell refers

130 to the final cell number in each well. Final cell number in mTeSR $1+$ serum and mTeSR1

$131+$ KOSR was adjusted to reflect the cell loss seen in these conditions, estimated to be a

132 total of $11 \%$ over a 24 hour period.

133 Measurement of carbohydrate consumption and production

134 Glucose concentration in the media was estimated using an enzymatic assay linked to

135 NADPH production. One $\mu \mathrm{L}$ of medium, previously diluted 1:10 in water, was added to 
$13610 \mu \mathrm{L}$ of glucose reagent $\left(3.7 \mathrm{mM} \mathrm{MgSO}_{4} .7 \mathrm{H}_{2} \mathrm{O}, 0.6 \mathrm{mM} \mathrm{NADP}^{+}, 0.5 \mathrm{mM}\right.$ ATP, $0.5 \mathrm{mM}$

137 dithiothreitol, $12 \mathrm{U}$ hexokinase/mL, and $6 \mathrm{U}$ G6PDH/mL in EPPS buffer with $\mathrm{pH}$ 8.0)

138 (Gardner and Leese 1990). Similarly, lactate concentration in the media was estimated

139 using an enzymatic assay linked to NADH production. Two $\mu \mathrm{L}$ of medium, previously

140 diluted 1:10 with water, were added to $10 \mu \mathrm{L}$ of lactate reagent $\left(4.76 \mathrm{mM} \mathrm{NAD}^{+}, 100 \mathrm{U}\right.$

$141 \mathrm{LDH} / \mathrm{mL}$, and 2.6 mM EDTA in glycine-hydrazine buffer with pH 9.4) (Gardner and

142 Leese 1990). Fluorescence was measured using a Nanodrop 3300 Fluorospectrometer

143 (Thermo Fisher Scientific).

144 The percentage of glycolysis was calculated based on one mole of glucose yields two

145 moles of lactate $(\%$ of glycolysis $=\#$ of moles of lactate / $(\#$ of moles of glucose $\times 2))$.

146 Measurement of amino consumption and production with Liquid Chromotography-Mass

147 Spectrometry (LC-MS)

148 The concentration of amino acids in the culture media was measured by LC-MS. All

149 materials used for derivatisation of amino acids in the media and amino acid standards

150 were from Sigma-Aldrich. To derivatise amino acids, $10 \mu \mathrm{L}$ of medium, diluted 1:30 in

151 water, was added to $70 \mu \mathrm{L}$ of borate buffer $(200 \mathrm{mM}, \mathrm{pH}=8.8)$, followed by the addition

152 of $20 \mu \mathrm{L}$ of 6-aminoquinolyl- $N$-hydroxysuccinimidyl carbamate (AQC) solution (3 mg of

153 AQC dissolved in $1 \mathrm{~mL}$ of dry acetonitrile). Reactions were shaken at $55^{\circ} \mathrm{C}$ for 10

154 minutes before LC-MS analysis on an Agilent 6410 LC-ESI-QQQ equipped with an

155 Agilent 1200 Series LC system (Agilent Technologies). A Multiple Reaction Monitor

156 was developed for each individual amino acid. Conditions were capillary temperature

$157300^{\circ} \mathrm{C}$, capillary voltage $4000 \mathrm{~V}$, and gas flow rate $10 \mathrm{~L} /$ minute. The concentration of

158 each amino acid was obtained in every sample.

Culture environment regulates human ES cells

3 April 2013 
Determination of amino acid turnover:

160 The measurement of turnover was adapted from the approach of Houghton et al.

161 (Houghton et al. 2002), and represents the sum, in fmol/cell/hour of amino acids

162 consumed or released into the culture medium. Total amino acid turnover was the sum of

163 amino acid change in fmol/cell/hour.

\section{Immunofluorescence}

165 Human ES cells were cultured on Matrigel ${ }^{\mathrm{TM}}$-treated glass coverslips in $\mathrm{mTeSR} 1$ and

166 supplements as described in the text. Cells were washed with PBS and fixed with 4\%

167 PFA. Fixed monolayers were made permeable with PBS/0.25\% TritonX, blocked with

$1681 \%$ BSA or donkey serum. Antigens were detected with antibodies directed against

169 NANOG (R\&D Systems) or phospho-histone H3 (Ser10) (Cell Signaling Technologies)

170 in combination with an Alexa-Fluor 488 conjugated anti-goat antibody (NANOG; Life

171 Technologies) or an Alexa-Fluor 568 conjugated anti-rabbit antibody (Phospho-Histone

172 H3 (Ser10); Life Technologies); DNA was detected with DAPI. Images were taken on an

173 Olympus BX50 microscope with an Olympus F-viewII digital camera (NANOG) or a

174 confocal microscope (Phospho-Histone H3 (Ser10). Percentage of mitotic cells was

175 calculated as the percentage of DAPI nuclei positive for phospho-histone H3 (Ser10) in

176 randomly captured fields.

\section{Statistical analysis}

178 Gene expression and carbohydrate use were analysed by Student's two-tailed t-test.

179 Analysis of the variance in amino acid use in control samples was performed using

180 ANOVA. Analysis of amino acid use in experimental samples, in comparison with the

181 controls, was performed using the $\mathrm{R}$ statistical software package with in-house 
182 customized scripts. A logarithm transformation was applied to all metabolite

183 concentration measurements to minimize heteroscedastic noise to ensure a Gaussian data

184 distribution prior to analysis. A two-tailed paired Student's t-test was used to calculate

185 significant differences between the means of metabolite concentration responses.

186 Manhattan Hierarchical Cluster Analysis was undertaken to confirm reproducibility of

187 sample replicates and to determine the relationships between metabolites based on a

188 measure of distance similarity. Pearson Correlation Analysis was conducted on the

189 logarithm transformed metabolite measurements to confirm relationships of metabolite

190 consumption. For all analyses, a $P$-value of less than 0.05 was considered statistically

191 significant. 


\section{Results}

\section{Serum induces sporadic differentiation of human ES cells.}

194 The human ES cell line MEL2 (Australian Stem Cell Centre) was cultured in mTeSR1

195 for 72 hours followed by 96 hours in mTeSR1 supplemented with one of two foetal calf

196 sera at a concentration of $20 \%$. The sera used in this experiment had been selected for use

197 with mouse ES cells and shown to elicit low levels of cell differentiation (Rathjen and

198 Rathjen 2003) (Dr Jeff Mann, Murdoch Childrens Research Institute, Parkville, Victoria;

199 unpublished). In mTeSR1, human ES cells grew in tightly-packed colonies with smooth

200 edges (Figure 1A)(Ludwig et al. 2006b). The addition of serum resulted in a loosening of

201 the cells at the edge of the colonies and formation of a border region comprising

202 fibroblast-like cells (Figure 1B). Comparable alterations in morphology were observed

203 with both sera tested (Figure 1B, C).

204 Expression levels of the pluripotent markers OCT4 and NANOG in cells cultured in

205 serum remained high and similar to cells cultured in mTeSR1 alone, although a small but

206 consistent reduction in NANOG expression was observed with both sources of sera

207 (Figure 1D). This reflected the substantial pool of pluripotent cells in cultures, as shown

208 by immunocytochemistry (Figure 1E). Only cells at the edge of the colonies had reduced

209 NANOG protein levels, while the majority of the cells within the colonies remained

210 NANOG positive. Markers of differentiation, BRACHYURY and GATA4, were elevated in

211 cells cultured in serum. The fold increase of these markers was variable between

212 experimental repeats suggesting that the proportion of differentiated cells in populations

213 cultured in serum was unpredictable. The reduction in NANOG expression, expression of

214 differentiation markers and morphology changes, however, suggested a heterogeneous 
215 population of cells in serum in which the frequency of differentiated cells was increased.

216 A similar heterogeneity has been seen in mouse ES cells cultured in serum-supplemented

217 medium when compared to those cultured in defined medium (Marks et al. 2012).

218 Differentiation of mouse ES cells in response to serum requires p38 MAPK activity (CY

219 and JR unpublished). P38 MAPK activity can be inhibited pharmacologically with

220 SB203580 (4-(4'-fluorophenyl)-2-(4'-methylsulfinylphenyl)-5-(4'-pyridyl)-imidazole),

221 which inhibits $\mathrm{p} 38 \alpha, \mathrm{p} 38 \beta$ and p38 32 homologues by competing for ATP binding pockets

222 (Cuenda et al. 1995). The expression of pluripotent and differentiated markers were

223 analysed in cells cultured in mTeSR1 + FCS and compared to expression in cells cultured

224 in mTeSR1 + FCS + SB203580. Expression of OCT4 was significantly increased, and

225 BRACHYURY and GATA4 significantly decreased, in cells cultured in mTeSR1 + serum

$226+$ SB203580 (Figure 1F). These data confirm an increase in differentiation in cells

227 cultured in serum and suggest a requirement for p38 MAPK in the process.

\section{Serum induces alterations in the metabolic activity of human ES cells in culture.}

229 Carbohydrate use by human ES cells cultured in mTeSR1 was compared to that of cells

230 exposed to serum for 24 and 96 hours. The measured concentration of glucose and lactate

231 in mTeSR1 and mTeSR1 + serum can be found in Table S2. Cells cultured in serum

232 consumed more glucose and produced more lactate than controls (Table 1). Glucose

233 consumption approximately doubled with 96 hours of exposure to serum. Although more

234 glucose was being metabolised by cell cultures exposed to serum, the percentage of

235 glucose metabolised glycolytically in these cells was not altered when compared to cells

236 cultured in mTeSR1 (Table 1). 
237 In the published formulation of mTeSR the medium includes amino acids in a range of

238 concentrations standard for tissue culture maintenance. Repeated measurement of mTeSR

239 confirmed the presence and the concentration of amino acids in the medium, and

240 provided confidence that the technology used could reliably measure amino acids within

241 medium samples (Figure S1). In mTeSR1 + serum the concentrations of alanine, glutamic

242 acid and glycine were significantly increased when compared to mTeSR (Table S3). The

243 concentration of amino acids in medium used for culturing human ES cells was

244 determined and compared to unused medium. Cells cultured in mTeSR1 or mTeSR1 +

245 serum produced alanine, glutamic acid, proline and ornithine (Figure 2A). The production

246 of glutamic acid was significantly higher from cells cultured in serum (Figure 2A).

247 Human ES cells consumed arginine, cysteine, glutamine, glycine, isoleucine, leucine,

248 lysine, methionine, phenylalanine, serine, threonine, tryptophan, tyrosine, valine and $\gamma$ -

249 aminobutyric acid (GABA) (Figure 2A). The addition of serum to the culture medium

250 significantly increased the consumption of the majority of these amino acids (Figure 2A).

251 Overall, the addition of serum increased the total turnover of amino acids by the cells 1.9-

252 fold to $106 \mathrm{fmol} /$ cell/hour (Figure 2B), comprised of a 1.7-fold increase in amino acid

253 production and a 1.9-fold increase in amino acid consumption.

254 Differentiation of human ES cells in response to BMP4 does not alter the carbohydrate 255 usage or amino acid metabolism.

256 Metabolism in pluripotent cells and somatic cells differs, suggesting that the changes in

257 glucose use and amino acid turnover in serum could arise from differentiated cells in the

258 population. Alternatively, changes in metabolomic activity could result from serum-

259 induced changes in the activity of all cells. The differentiation of human ES cells was 
260 induced by the addition of BMP4 to mTeSR1 for 4 days (Hughes et al. 2009) and

261 carbohydrate usage and amino acid metabolism were measured. Like serum, BMP4

262 induces expression of Brachyury and Gata4 (Kobayashi et al. 2008; Hughes et al.

263 2009)(CY and JR unpublished) and is likely to result in a repertoire of cells that overlaps

264 those formed in serum.

265 As expected, the addition of BMP4 resulted in an overtly differentiated colony

266 morphology with each colony consisting of a small core of pluripotent, NANOG positive,

267 cells surrounded by cells of an overtly differentiated phenotype (Figure 3A,B and data

268 not shown). Previous analysis has demonstrated the decreased expression of NANOG and

269 increased expression of differentiation markers in human ES cells exposed to BMP4

270 (Hughes et al. 2009). The analysis of spent medium from these cultures did not show any

271 changes in the consumption of glucose, production of lactate or percentage glycolysis

272 when compared to cells cultured in mTeSR1 (Table 1). Similarly, the addition of BMP4

273 had little effect on production or consumption of the amino acids tested, with differences

274 detected only in consumption of tryptophan and production of glutamic acid and proline,

275 and no overall change in amino acid turnover (Figure 3C, D).

276 Knockout ${ }^{\mathrm{TM}}$ SR induces metabolic changes in human ES cells.

277 Knock-out serum replacer (Knockout ${ }^{\mathrm{TM}}$ SR; Life Technologies) is commonly used as a

278 medium supplement for the growth and differentiation of human ES cells (Adewumi et

279 al. 2007). Knockout ${ }^{\mathrm{TM}} \mathrm{SR}$ was added to mTeSR1 and the effects on human ES cell

280 growth and metabolism were measured. Addition of $20 \%$ Knockout $^{\text {TM }}$ SR to mTeSR1

281 resulted in minor alterations in colony morphology, with some fibroblast-like cells 
282 appearing at the edge of the colonies (Figure 4A, B). The change in colony morphology

283 was, however, much reduced in comparison to cells exposed to serum or BMP4.

284 Similarly, gene expression analysis of these cells did not detect any reduction in NANOG

285 expression or increase in the expression of the differentiation markers (Figure 4C).

286 Carbohydrate use by cells exposed to Knockout ${ }^{\mathrm{TM}}$ SR for 96 hours was compared to use

287 by cells cultured in mTeSR1 (Table 1). Knockout ${ }^{\mathrm{TM}}$ SR increased the consumption of

288 glucose and production of the lactate by approximately 1.4 fold. These changes were not

289 accompanied by a change in the percentage of glucose metabolised glycolytically.

290 The measurement of amino acid concentrations in medium containing Knockout ${ }^{\text {TM }}$ SR

291 showed several amino acids, isoleucine, phenylalanine, proline, serine, threonine,

292 tryptophan and valine, to be present at unusually high concentrations when compared to

293 mTeSR1 (Table S4). These concentrations were not, however, unexpected when the

294 preferred embodiment of the medium contained within the patent describing the

295 formulation of Knockout ${ }^{\mathrm{TM}}$ SR is considered (Price 1998). The profile of amino acids

296 produced and consumed from cells exposed to Knockout ${ }^{\mathrm{TM}}$ SR was significantly different

297 from that of cells cultured in mTeSR1, and from cells exposed to serum or BMP4. Cells

298 in Knockout ${ }^{\mathrm{TM}}$ SR produced glycine, isoleucine, phenylalanine, threonine, valine and

299 GABA (Figure 5A). In contrast, cells cultured in mTeSR, mTeSR + serum and mTeSR +

300 BMP4 consumed these amino acids. The production of alanine, glutamic acid, and

301 proline, and the consumption of lysine and serine, was significantly increased by the

302 addition of Knockout ${ }^{\mathrm{TM}}$ SR (Figure 5A). Overall turnover of amino acids by cells

303 cultured in Knockout ${ }^{\mathrm{TM}}$ SR was increased 1.9-fold, to $109 \mathrm{fmol} /$ cell/hour (Figure 5B).

304 Although this value was similar to the increase in amino acid turnover seen from cells 
305 cultured in serum, the changes in production and consumption contributing to this were

306 different, with a 4.6 fold increase in amino acid production and $12 \%$ reduction in amino

307 acids consumed.

308 Cell proliferation is not affected by the addition of serum or Knockout ${ }^{\mathrm{TM}}$ SR.

309 The addition of serum or Knockout ${ }^{\mathrm{TM}}$ SR potentially alters the growth characteristics of

310 human ES cells and affects the requirement of these cells for nutrients. The proportion of

311 cells in mitosis, identified by staining for phospho-histone H3 (Ser10), in human ES cells

312 cultured in mTeSR1 or mTeSR1 supplemented with serum or Knockout ${ }^{\mathrm{TM}}$ SR was

313 measured. No significant difference in cell proliferation was detected (Table 2). The

314 addition of serum or Knockout ${ }^{\mathrm{TM}} \mathrm{SR}$, however, did reduce the number of cells in culture

315 by approximately $50 \%$ at the time of assay (Table 3 ). 


\section{Discussion}

317 The establishment of human ES cells by Thomson and colleagues in 1998 has resulted in

318 a dramatic increase in publications analysing the genetics, epigenetics and differentiation

319 of these cell lines, including multiparticipant studies that compared these characteristics

320 across multiple human ES cell lines (Adewumi et al. 2007; Akopian et al. 2010; Amps et

321 al. 2011). In contrast, there has been relatively little investigation of the physiology of

322 these cells, even when the suitability of medium formulations for human ES cell culture

323 is being tested (Akopian et al. 2010). Cellular metabolism is fundamental to embryo

324 viability and cell function (Gardner 1998; Lane and Gardner 2005), and has been shown

325 to be adapted in cells as they acquire characteristics of cancer and disease (Fritz and Fajas

326 2010; Chang and Wei 2011). If the clinical and commercial potential of human ES cells

327 is to be realized, a greater understanding of metabolic activity and regulation of metabolic

328 processes during stem cell derivation and differentiation will need to be acquired and

329 media formulations that support an appropriate metabolic state developed. Physiological

330 markers of pluripotency will find future applications in the validation and accreditation of

331 existing and newly isolated human ES cell lines.

332 In this study mTeSR1 was chosen as a standard human ES cell culture system against

333 which to compare the effect of supplements and differentiation on metabolism. mTeSR1

334 supports the growth of human ES cells in the absence of a feeder layer that would

335 otherwise complicate analysis (Ludwig et al. 2006a; Akopian et al. 2010). mTeSR1 has

336 been disclosed, which allows experimental measurements to be compared with the

337 published formulation (Ludwig et al. 2006a). The medium is based on a widely used

338 medium, DMEM:F12 mix, and provides salts, nutrients and amino acids at concentrations 
339 previously determined to be sufficient for the culture of mammalian cells in culture and

340 extensively used for the culture of mouse pluripotent cells and human ES cells. The

341 medium contains a high concentration $(13.7 \mathrm{mM})$ of glucose as an energy source. After

34224 hours of culture in wells containing near confluent cell colonies the medium contained

343 approximately one third of starting glucose, a final concentration of between 4 and $5 \mathrm{mM}$.

344 The osmolality of supplemented medium remained within the normal range (data not

345 shown). Medium supplementation will, however, have modified the composition of the

346 medium and altered the concentration of growth factors in the formulation. Adding $20 \%$

347 F12 to mTeSR1 did not alter cell proliferation, cell viability, or induce signs of

348 differentiation (Figure S2; Table S5), suggesting that diluted mTeSR maintained human

349 ES cells over the time course of this experiment.

350 The addition of serum or Knockout ${ }^{\mathrm{TM}} \mathrm{SR}$ did not alter the rate of ES cell division, a

351 surprising result given the well-established role of serum in stimulating cell proliferation

352 in culture (Shodell and Rubin 1970). The cell cycle of mouse (Stead et al. 2002) and

353 human (Kapinas et al. 2013) ES cells is rapid, characterized by truncated gap phases and

354 distinct in structure from the cell cycle of somatic cells. In mouse, Cdk2, cyclin A and

355 cyclin E kinases are active throughout the cell cycle and lack the cell cycle periodicity

356 that is seen in somatic cells (Stead et al. 2002). The inability of serum to stimulate

357 pluripotent cell proliferation is likely a consequence of the unique characteristics of the

358 pluripotent cell cycle structure. The addition of the supplements did alter cell viability

359 and resulted in fewer cells surviving the period of treatment when compared to the 360 controls.

361 Glucose uptake and energy use are increased by serum and Knockout ${ }^{\mathrm{TM}}$ SR 
362 In mTeSR medium human ES cells used glucose as an energy source, with an estimated

$36350 \%$ of the glucose metabolized to lactate through glycolysis. The high contribution of

364 glycolysis to the energy needs of human ES cells is consistent with previous reports

365 (Prigione et al. 2010; Varum et al. 2011; Zhang et al. 2011). The use of glycolysis when

366 cultured in high oxygen tension $\left(20 \% \mathrm{O}_{2}\right)$, known as aerobic glycolysis, is a feature

367 shared with cancer cells and other rapidly proliferating cells in culture, and may reflect

368 the continual proliferation, or self-renewal, of human ES cells (Warburg 1956; Morgan

369 and Faik 1981; Brand et al. 1988; Fox et al. 2005; Lopez-Lazaro 2008; Gardner and Wale

370 2013; Harvey et al. In press).

371 The addition of serum or Knockout ${ }^{\mathrm{TM}} \mathrm{SR}$ increased the amount of glucose used by the

372 cells but did not appear to alter the percentage of the glucose metabolized to lactate,

373 indicating that these supplements increased the energy requirements of the cells.

374 Carbohydrate use by mouse ES cells has been shown to be sensitive to medium

375 composition, with increased glucose uptake from serum-containing medium when

376 compared to medium supplemented with Knockout ${ }^{\mathrm{TM}}$ SR (Fernandes et al. 2010b).

377 Increased glucose uptake in cells cultured in serum could result from a higher flux of

378 glucose in differentiated cells within the population or from increased glucose flux in

379 human ES cells. Increased glucose flux in cells cultured in Knockout ${ }^{\text {TM }}$ SR cannot be

380 explained by differentiation, and increasing the proportion of differentiated cells in the

381 human ES cell population, by inducing differentiation with BMP4, did not affect

382 carbohydrate use. These data suggest that the effect of serum and serum replacement on

383 glucose uptake was a consequence of the effect of medium composition. It cannot be

384 excluded that this effect was driven, in part, by dilution of mTeSR1 with the supplements. 
387 The analysis of amino acid turnover during culture was used as a second indicator of

388 metabolite flux in human ES cells. Cells cultured in serum-supplemented mTeSR1

389 exhibited a 1.9-fold increased turnover of amino acids when compared to cells cultured in

390 mTeSR1; this increase was a consequence of an approximately 1.9-fold increase in the

391 use and production of amino acids by the population. As with glucose consumption,

392 increased amino acid turnover could be a consequence of the increase in differentiated

393 cells within the population. The addition of BMP4 to mTeSR increased cell

394 differentiation but had little effect on the consumption or production of amino acids, with

395 amino acid turnover similar between cells cultured in mTeSR and BMP4 and mTeSR

396 alone and only minor variations in the turnover of tryptophan, glutamic acid and proline

397 observed.

399 Cells cultured in mTeSR + Knockout ${ }^{\text {TM }}$ SR also showed a 1.9-fold increase in amino acid

400 turnover. Unlike the increased turnover in serum, which affected all amino acids to a

401 similar degree, the increased turnover in cells cultured in Knockout ${ }^{\mathrm{TM}} \mathrm{SR}$ comprised a

402 prodigious 4.6 -fold increase in amino production coupled with a modest $12 \%$ decrease in

403 amino acid consumption. These changes occur without any overt differentiation in the

404 population suggesting they arise from a direct effect of Knockout ${ }^{\mathrm{TM}} \mathrm{SR}$ on the human ES

405 cell. Collectively, these data demonstrate that the interaction of serum and Knockout ${ }^{\mathrm{TM}}$

406 SR with human ES cells resulted in a considerable up regulation of amino acid turnover. 
407 Although similar in scale, increases in turnover resulted from specific cell responses to

408 the medium composition.

\section{Differentiation and metabolic change are not coincident.}

410 The metabolism of pluripotent cells and somatic cells are different, which suggests that

411 differentiation will be accompanied by changes in metabolic activity and metabolic

412 pathway use. The differentiation of mouse ES cells has been shown to change

413 carbohydrate use (Kondoh et al. 2007; Fernandes et al. 2010a), and the differentiation of

414 human ES cells in response to retinoic acid (RA) has been shown to decrease glycolysis

415 (Zhang et al. 2011). In contrast, inducing differentiation of human ES cells with BMP4 in

416 mTeSR1 did not change carbohydrate use or glycolytic flux. The timing and regulation

417 of the metabolic changes that accompany differentiation are largely unexplored but

418 changes in metabolism occurred gradually when human ES cells were differentiated with

419 RA (Zhang et al. 2011). The unchanged carbohydrate use in BMP4-treated human ES

420 cells after 4 days potentially reflects the gradual nature of change, but may also be

421 impacted by the cell population formed and the medium used. Amino acid turnover was

422 also largely unaffected by human ES cell differentiation. Measuring the intracellular

423 metabolites present in mouse ES cells as they differentiate has shown no change in amino

424 acid concentrations, with the exception of an increase in threonine, and few changes in

425 other metabolites that were measured (Wang et al. 2009). These data suggest that in the

426 early stages of pluripotent cell differentiation, as examined here, changes in metabolism

427 lag behind the loss of pluripotence.

Culture environment regulates human ES cells 
428 Changes in the turnover of individual amino acids can be used as indicators of

429 changes in cell metabolism

430 Cells cultured in serum supplemented medium consumed significantly more glutamine

431 than those cultured in control medium or mTeSR medium supplemented with BMP4 or

432 Knockout ${ }^{\mathrm{TM}}$ SR. Several proliferating cell types, including cancer cells (DeBerardinis et

433 al. 2007), metabolise glutamine to $\alpha$-ketoglutarate via the formation of glutamate

434 (glutaminolysis), a process that liberates ammonium. The increased glutamine

435 consumption by human ES cells cultured in serum is consistent with increased

436 glutaminolysis and potentially reflects an increased flux of glutamine metabolites through

437 the tricarboxylic acid cycle (TCA) cycle. The increased production of glutamic acid and

438 alanine from cells could be a defensive strategy to alleviate the toxicity of the ammonium

439 formed as a consequence of serum exposure (Morgan and Faik 1981; Weinberg and

440 Chandel 2009). Glutamine consumption was not increased in mTeSR + Knockout ${ }^{\mathrm{TM}} \mathrm{SR}$

441 or mTeSR + BMP4 suggesting that neither of these conditions induced increases in

442 glutaminolysis.

443 The maintenance of pluripotency, and stable glutamine consumption, by Knockout ${ }^{\mathrm{TM}}$ SR

444 is consistent with this supplement being more compatible with the physiological needs of

445 human ES cells than serum. The addition of Knockout ${ }^{\mathrm{TM}} \mathrm{SR}$ to mTeSR, however,

446 significantly altered the concentration of specific amino acids in the medium, increasing

447 their concentration by as much as 30 -fold, as is the case for proline (Table S4). The

448 inclusion of Knockout ${ }^{\mathrm{TM}}$ SR resulted in profound changes in the way that amino acids

449 were utilized by the cells. In general, amino acids with increased concentrations in

450 Knockout ${ }^{\mathrm{TM}}$ SR supplemented medium were produced by cells cultured in Knockout ${ }^{\mathrm{TM}}$ 
451 SR but consumed by cells cultured in control medium; this was seen for glycine,

452 histidine, isoleucine, phenylalanine, threonine, tryptophan and valine. This was the only

453 medium formulation analysed that elicited changes from the consumption to production

454 of amino acids by the cells. The consumption of serine and production of proline, in

455 contrast, did not change to production and consumption, respectively, despite these amino

456 acids being increased with the addition of Knockout ${ }^{\mathrm{TM}} \mathrm{SR}$ to mTeSR. For both of these

457 amino acids, however, the magnitude of amino acid turnover was significantly increased.

458 Finally, significant changes were seen in the turnover of alanine, lysine and glutamic acid

459 by cells cultured in Knockout ${ }^{\mathrm{TM}} \mathrm{SR}$. The concentrations of these amino acids did not

460 differ between supplemented medium and the control.

461 The changes in amino acid production detected in cells cultured in Knockout ${ }^{\mathrm{TM}} \mathrm{SR}$

462 indicated that multiple biosynthetic pathways were affected, which suggests a model in

463 which a general control process, such as those mediated by mTOR or GCN2 (Bruhat et

464 al. 2000; Kim 2009; Sancak et al. 2010), regulated biosynthetic activation across a

465 number of pathways. Counter intuitively, cells may perceive an amino acid limitation in

466 medium in which amino acid concentrations are not balanced. Elevated concentrations of

467 one amino acid can compromise the ability of a cell surface transporter of amino acids to

468 function and limit uptake of other amino acids. For example, the level of L-proline in

469 Knockout ${ }^{\mathrm{TM}}$ SR-supplemented medium is sufficient to inhibit SNAT2 uptake of a number

470 of amino acids, including glycine, alanine, serine, cysteine, glutamic acid, asparagine,

471 histidine and methionine (Tan et al. 2011), and may limit transport of these amino acids

472 into the cell, starving the cell of required nutrients and activating the amino acid sensing

473 pathways. Transporter-mediated amino acid limitation has been shown to regulate mTOR 
474 signaling and activate the GCN2 pathway in vivo (Broer et al. 2011; Pinilla et al. 2011).

475 Activation of the amino acid sensing pathways, and downstream regulation of

476 biosynthetic pathways, could explain the changes in amino acids production in cells

477 cultured in Knockout ${ }^{\mathrm{TM}}$ SR. Although these changes to biosynthesis do not appear to alter

478 the pluripotency of the cells, it is likely changes of this magnitude will impact on other

479 aspects of cell function, including an increase in energy requirements. More analysis will

480 be required before the impact of Knockout ${ }^{\mathrm{TM}}$ SR on amino acid biosynthesis in human

481 ES cells can be understood but these data question the suitability of Knockout ${ }^{\mathrm{TM}}$ SR in its

482 current formulation for human ES cells culture.

483 Amino acids can be used by cells for biosynthesis, energy production and as signaling

484 molecules. Recently, a role for proline as a signaling molecule in pluripotent cell

485 differentiation in culture has been described (Washington et al. 2010; Tan et al. 2011).

486 Human ES cells cultured in mTeSR produced proline and production by cells cultured in

487 mTeSR + serum and mTeSR + Knockout ${ }^{\mathrm{TM}}$ SR was significantly increased; in

488 Knockout ${ }^{\mathrm{TM}}$ SR proline production was increased approximately 10-fold. Proline

489 production was significantly reduced with BMP4-induced differentiation suggesting that

490 the production of proline is a feature of the pluripotent cells. The elevated concentrations

491 of proline within the medium, either as a consequence of the elevated production of

492 proline by the cells or the addition of proline to the medium, could potentially alter the

493 pluripotent cell state or affect the stability of human ES cells in culture (Pera and Tam

494 2010; Washington et al. 2010; Tan et al. 2011).

495 The maintenance of high levels of pluripotency and inhibition of differentiation are the

496 key indicators that have been used to date to drive the development of culture conditions 
497 for human ES cells. Although important these indicators do not reflect the physiology of

498 the cells; it is clear that the interaction of human ES cells with the medium can induce

499 significant alterations in carbohydrate use and amino acid turnover without necessarily

500 impacting on pluripotency. Addition of the supplements also affected cell growth, with

501 no change in the proliferation rate but significant cell loss from the populations during the

502 assay potentially reflecting a reduction in cell viability as a result of cell stress. The effect

503 of altered physiology on human ES cells and their differentiated derivatives is not known

504 but a wealth of studies of the early embryo suggest that the impact of sub-optimal culture

505 conditions and altered metabolism can be far reaching and affect long-term development

506 outcomes, potentially through interaction with the epigenome (Donohoe and Bultman

507 2012). The work reported here provides baseline measurements of carbohydrate use and

508 amino acid turnover in human ES cells cultured without feeders and in a fully described,

509 serum-free medium and establishes a model system that can be used to assess the effects

510 of environmental modulation on human ES cell metabolism, signaling pathway activity,

511 transcriptome and epigenome. Further studies are underway to characterise the fluxome

512 of human ES cells under these conditions, extending the observations reported here to a

513 more comprehensive range of metabolic pathways and processes.

514 Like serum, oxygen has been negatively associated with embryo metabolism and

515 outcome (Wale and Gardner 2012). There is a growing literature describing the effects of

516 ambient and reduced oxygen tensions on embryonic stem cells in culture. A number of

517 reports have shown increased pluripotency marker expression (Prasad et al. 2009;

518 Forristal et al. 2010), improved chromosomal stability (Forsyth et al. 2006), decreased

519 differentiation (Ezashi et al. 2005; Prasad et al. 2009; Zachar et al. 2010), increased 
520 glycolysis (Kondoh et al. 2007), altered oxygen uptake rates (Abaci et al. 2010),

521 enhanced derivation of mouse (Gibbons et al. 2006) and human (Peura et al. 2007) ES

522 cells, and improved generation of iPS cells from mouse embryonic fibroblasts (Yoshida

523 et al. 2009) in lower oxygen tensions. There are, however, reports that have failed to

524 demonstrate significant differences between cells cultured in ambient and reduced

525 oxygen tensions (Ezashi et al. 2005; Forsyth et al. 2006; Prasad et al. 2009; Zachar et al.

526 2010). Comparison of these studies is hampered by the lack of consistency in other

527 components of the culture system, which could mask or accentuate the potentially subtle

528 effects elicited by oxygen, and the variable use of metabolic indicators, some of which

529 may be insensitive to oxygen tension. To achieve medium optimization we envisage that

530 the analysis of individual components of the culture environment, like amino acid

531 concentrations, protein supplements and oxygen tension, will need to be followed by

532 multifactorial and high-throughput approaches assessing combinations of selected

533 conditions and a range of sensitive and robust metabolic markers. 


\section{Acknowledgements}

536 The authors would like to thank Dr. John Sheedy (University of Melbourne) for

537 assistance with the data analysis, Ms. Natasha Dodge, Ms. Mai Truong and Ms. Jackie

$538 \mathrm{Yu}$ for technical assistance and Dr. Jeff Mann for the ES cell-tested serum. This work

539 was supported by a Linkage grant from the Australian Research Council and Molecular

540 Biometrics Pty. Ltd. (Conneticut, USA). 


\section{References}

543

544

545

546

547

548

549

550

551

552

553

554

555

556

557

558

559

560

561

562

563

564

565

566

567

568

569

570

571

572

573

574

575

576

577

578

579

580

581

582

583

584

Abaci, H.E., Truitt, R., Luong, E., Drazer, G., and Gerecht, S. (2010) Adaptation to oxygen deprivation in cultures of human pluripotent stem cells, endothelial progenitor cells, and umbilical vein endothelial cells. Am J Physiol Cell Physiol 298(6), C1527-37

Adewumi, O., Aflatoonian, B., Ahrlund-Richter, L., Amit, M., Andrews, P.W., Beighton, G., Bello, P.A., Benvenisty, N., Berry, L.S., Bevan, S., Blum, B., Brooking, J., Chen, K.G., Choo, A.B., Churchill, G.A., Corbel, M., Damjanov, I., Draper, J.S., Dvorak, P., Emanuelsson, K., Fleck, R.A., Ford, A., Gertow, K., Gertsenstein, M., Gokhale, P.J., Hamilton, R.S., Hampl, A., Healy, L.E., Hovatta, O., Hyllner, J., Imreh, M.P., ItskovitzEldor, J., Jackson, J., Johnson, J.L., Jones, M., Kee, K., King, B.L., Knowles, B.B., Lako, M., Lebrin, F., Mallon, B.S., Manning, D., Mayshar, Y., McKay, R.D., Michalska, A.E., Mikkola, M., Mileikovsky, M., Minger, S.L., Moore, H.D., Mummery, C.L., Nagy, A., Nakatsuji, N., O'Brien, C.M., Oh, S.K., Olsson, C., Otonkoski, T., Park, K.Y., Passier, R., Patel, H., Patel, M., Pedersen, R., Pera, M.F., Piekarczyk, M.S., Pera, R.A., Reubinoff, B.E., Robins, A.J., Rossant, J., Rugg-Gunn, P., Schulz, T.C., Semb, H., Sherrer, E.S., Siemen, H., Stacey, G.N., Stojkovic, M., Suemori, H., Szatkiewicz, J., Turetsky, T., Tuuri, T., van den Brink, S., Vintersten, K., Vuoristo, S., Ward, D., Weaver, T.A., Young, L.A., and Zhang, W. (2007) Characterization of human embryonic stem cell lines by the International Stem Cell Initiative. Nat Biotechnol 25(7), 803-16

Akopian, V., Andrews, P.W., Beil, S., Benvenisty, N., Brehm, J., Christie, M., Ford, A., Fox, V., Gokhale, P.J., Healy, L., Holm, F., Hovatta, O., Knowles, B.B., Ludwig, T.E., McKay, R.D., Miyazaki, T., Nakatsuji, N., Oh, S.K., Pera, M.F., Rossant, J., Stacey, G.N., and Suemori, H. (2010) Comparison of defined culture systems for feeder cell free propagation of human embryonic stem cells. In Vitro Cell Dev Biol Anim 46(3-4), 247-58

Amps, K., Andrews, P.W., Anyfantis, G., Armstrong, L., Avery, S., Baharvand, H., Baker, J., Baker, D., Munoz, M.B., Beil, S., Benvenisty, N., Ben-Yosef, D., Biancotti, J.C., Bosman, A., Brena, R.M., Brison, D., Caisander, G., Camarasa, M.V., Chen, J., Chiao, E., Choi, Y.M., Choo, A.B., Collins, D., Colman, A., Crook, J.M., Daley, G.Q., Dalton, A., De Sousa, P.A., Denning, C., Downie, J., Dvorak, P., Montgomery, K.D., Feki, A., Ford, A., Fox, V., Fraga, A.M., Frumkin, T., Ge, L., Gokhale, P.J., Golan-Lev, T., Gourabi, H., Gropp, M., Lu, G., Hampl, A., Harron, K., Healy, L., Herath, W., Holm, F., Hovatta, O., Hyllner, J., Inamdar, M.S., Irwanto, A.K., Ishii, T., Jaconi, M., Jin, Y., Kimber, S., Kiselev, S., Knowles, B.B., Kopper, O., Kukharenko, V., Kuliev, A., Lagarkova, M.A., Laird, P.W., Lako, M., Laslett, A.L., Lavon, N., Lee, D.R., Lee, J.E., Li, C., Lim, L.S., Ludwig, T.E., Ma, Y., Maltby, E., Mateizel, I., Mayshar, Y., Mileikovsky, M., Minger, S.L., Miyazaki, T., Moon, S.Y., Moore, H., Mummery, C., Nagy, A., Nakatsuji, N., Narwani, K., Oh, S.K., Olson, C., Otonkoski, T., Pan, F., Park, I.H., Pells, S., Pera, M.F., Pereira, L.V., Qi, O., Raj, G.S., Reubinoff, B., Robins, A., Robson, P., Rossant, J., Salekdeh, G.H., Schulz, T.C., Sermon, K., Sheik Mohamed, J., Shen, H., Sherrer, E., Sidhu, K., Sivarajah, S., Skottman, H., Spits, C., Stacey, G.N., 
Strehl, R., Strelchenko, N., Suemori, H., Sun, B., Suuronen, R., Takahashi, K., Tuuri, T., Venu, P., Verlinsky, Y., Ward-van Oostwaard, D., Weisenberger, D.J., Wu, Y., Yamanaka, S., Young, L., and Zhou, Q. (2011) Screening ethnically diverse human embryonic stem cells identifies a chromosome 20 minimal amplicon conferring growth advantage. Nat Biotechnol 29(12), 1132-44

Brand, K., Aichinger, S., Forster, S., Kupper, S., Neumann, B., Nurnberg, W., and Ohrisch, G. (1988) Cell-cycle-related metabolic and enzymatic events in proliferating rat thymocytes. Eur J Biochem 172(3), 695-702

Brison, D.R., Houghton, F.D., Falconer, D., Roberts, S.A., Hawkhead, J., Humpherson, P.G., Lieberman, B.A., and Leese, H.J. (2004) Identification of viable embryos in IVF by non-invasive measurement of amino acid turnover. Hum Reprod 19(10), 2319-24

Broer, A., Juelich, T., Vanslambrouck, J.M., Tietze, N., Solomon, P.S., Holst, J., Bailey, C.G., Rasko, J.E., and Broer, S. (2011) Impaired nutrient signaling and body weight control in a $\mathrm{Na}+$ neutral amino acid cotransporter (Slc6a19)-deficient mouse. J Biol Chem 286(30), 26638-51

Bruhat, A., Jousse, C., Carraro, V., Reimold, A.M., Ferrara, M., and Fafournoux, P. (2000) Amino acids control mammalian gene transcription: activating transcription factor 2 is essential for the amino acid responsiveness of the CHOP promoter. Mol Cell Biol 20(19), 7192-204

Chang, X., and Wei, C. (2011) Glycolysis and rheumatoid arthritis. Int J Rheum Dis 14(3), 217-22

Cuenda, A., Rouse, J., Doza, Y., Meier, R., Cohen, P., Gallagher, T., Young, P., and Lee, J. (1995) SB 203580 is a specific inhibitor of a MAP kinase homologue which is stimulated by cellular stresses and interleukin-1. FEBS letters 364(2), 229-233

DeBerardinis, R.J., Mancuso, A., Daikhin, E., Nissim, I., Yudkoff, M., Wehrli, S., and Thompson, C.B. (2007) Beyond aerobic glycolysis: transformed cells can engage in glutamine metabolism that exceeds the requirement for protein and nucleotide synthesis. Proc Natl Acad Sci US A 104(49), 19345-50

Donohoe, D.R., and Bultman, S.J. (2012) Metaboloepigenetics: interrelationships between energy metabolism and epigenetic control of gene expression. J Cell Physiol 227(9), 3169-77

Ezashi, T., Das, P., and Roberts, R.M. (2005) Low O2 tensions and the prevention of differentiation of hES cells. Proc Natl Acad Sci U S A 102(13), 4783-8

Fernandes, T.G., Diogo, M.M., Fernandes-Platzgummer, A., da Silva, C.L., and Cabral, J.M. (2010a) Different stages of pluripotency determine distinct patterns of proliferation, 
metabolism, and lineage commitment of embryonic stem cells under hypoxia. Stem Cell Res 5(1), 76-89

Forristal, C.E., Wright, K.L., Hanley, N.A., Oreffo, R.O., and Houghton, F.D. (2010) Hypoxia inducible factors regulate pluripotency and proliferation in human embryonic stem cells cultured at reduced oxygen tensions. Reproduction 139(1), 85-97

Forsyth, N.R., Musio, A., Vezzoni, P., Simpson, A.H., Noble, B.S., and McWhir, J. (2006) Physiologic oxygen enhances human embryonic stem cell clonal recovery and reduces chromosomal abnormalities. Cloning Stem Cells 8(1), 16-23

Fox, C.J., Hammerman, P.S., and Thompson, C.B. (2005) Fuel feeds function: energy metabolism and the T-cell response. Nat Rev Immunol 5(11), 844-52

Fritz, V., and Fajas, L. (2010) Metabolism and proliferation share common regulatory pathways in cancer cells. Oncogene 29(31), 4369-77

Gardner, D.K. (1998) Changes in requirements and utilization of nutrients during mammalian preimplantation embryo development and their significance in embryo culture. Theriogenology 49(1), 83-102

Gardner, D.K. (2011) Analysis of embryo metabolism and the metabolome to identify the most viable embryo within a cohort. In 'Human Assisted Reproductive Technology.' (Eds. DK Gardner, BRMB Rizk and T Falcone) pp. 301-312. (Cambridge University Press: New York)

Gardner, D.K., and Leese, H.J. (1990) Concentrations of nutrients in mouse oviduct fluid and their effects on embryo development and metabolism in vitro. J Reprod Fertil 88(1), $361-8$

Gardner, D.K., and Wale, P.L. (2013) Analysis of metabolism to select viable human embryos. Fertil Steril In Press

Gardner, D.K., Wale, P.L., Collins, R., and Lane, M. (2011) Glucose consumption of single post-compaction human embryos is predictive of embryo sex and live birth outcome. Hum Reprod 26(8), 1981-6

Gibbons, J., Hewitt, E., and Gardner, D.K. (2006) Effects of oxygen tension on the establishment and lactate dehydrogenase activity of murine embryonic stem cells.

674 
675 Harvey, A.J., Rathjen, J., and Gardner, D.K. (In press) The metabolic framework of

676 pluripotent stem cells and potential mechanisms of regulation. In 'Stem Cells in

677 Reproductive Medicine. Vol. 3rd edition.' (Eds. C Simon, A Pellicer and R Reijo-Pera).

678 (Cambridge University Press: Cambridge)

679

680 Houghton, F.D., Hawkhead, J.A., Humpherson, P.G., Hogg, J.E., Balen, A.H.,

681 Rutherford, A.J., and Leese, H.J. (2002) Non-invasive amino acid turnover predicts

682

683

684

685

686

687

688

689

690

691

692

693

694

695

696

697

698

699

700

701

702

703

704

705

706

707

708

709

710

711

712

713

714

715

716

717

718

719

human embryo developmental capacity. Hum Reprod 17(4), 999-1005

Hughes, J.N., Dodge, N., Rathjen, P.D., and Rathjen, J. (2009) A novel role for gammasecretase in the formation of primitive streak-like intermediates from ES cells in culture. Stem Cells 27(12), 2941-51

Kapinas, K., Grandy, R., Ghule, P., Medina, R., Becker, K., Pardee, A., Zaidi, S.K., Lian, J., Stein, J., van Wijnen, A., and Stein, G. (2013) The abbreviated pluripotent cell cycle. $J$ Cell Physiol 228(1), 9-20

Khosla, S., Dean, W., Reik, W., and Feil, R. (2001) Culture of preimplantation embryos and its long-term effects on gene expression and phenotype. Hum Reprod Update 7(4), 419-27

Kim, E. (2009) Mechanisms of amino acid sensing in mTOR signaling pathway. Nutr Res Pract 3(1), 64-71

Kobayashi, M., Takada, T., Takahashi, K., Noda, Y., and Torii, R. (2008) BMP4 induces primitive endoderm but not trophectoderm in monkey embryonic stem cells. Cloning Stem Cells 10(4), 495-502

Kondoh, H., Lleonart, M.E., Nakashima, Y., Yokode, M., Tanaka, M., Bernard, D., Gil, J., and Beach, D. (2007) A high glycolytic flux supports the proliferative potential of murine embryonic stem cells. Antioxid Redox Signal 9(3), 293-9

Lane, M., and Gardner, D.K. (1996) Selection of viable mouse blastocysts prior to transfer using a metabolic criterion. Hum Reprod 11(9), 1975-8

Lane, M., and Gardner, D.K. (2005) Understanding cellular disruptions during early embryo development that perturb viability and fetal development. Reprod Fertil Dev 17(3), 371-8

Lopez-Lazaro, M. (2008) The warburg effect: why and how do cancer cells activate glycolysis in the presence of oxygen? Anticancer Agents Med Chem 8(3), 305-12

Ludwig, T.E., Bergendahl, V., Levenstein, M.E., Yu, J., Probasco, M.D., and Thomson, J.A. (2006a) Feeder-independent culture of human embryonic stem cells. Nat Methods 3(8), 637-46 
Ludwig, T.E., Levenstein, M.E., Jones, J.M., Berggren, W.T., Mitchen, E.R., Frane, J.L., Crandall, L.J., Daigh, C.A., Conard, K.R., Piekarczyk, M.S., Llanas, R.A., and Thomson, J.A. (2006b) Derivation of human embryonic stem cells in defined conditions. Nat Biotechnol 24(2), 185-7

Marks, H., Kalkan, T., Menafra, R., Denissov, S., Jones, K., Hofemeister, H., Nichols, J., Kranz, A., Stewart, A.F., Smith, A., and Stunnenberg, H.G. (2012) The transcriptional and epigenomic foundations of ground state pluripotency. Cell 149(3), 590-604

Morgan, M.J., and Faik, P. (1981) Carbohydrate metabolism in cultured animal cells. Biosci Rep 1(9), 669-86

Oddens, B.a.L., B. (2006) 'A decade of success in ART.' (Elsevier: Amsterdam)

Pera, M.F., and Tam, P.P. (2010) Extrinsic regulation of pluripotent stem cells. Nature 465(7299), 713-20

Peura, T.T., Bosman, A., and Stojanov, T. (2007) Derivation of human embryonic stem cell lines. Theriogenology 67(1), 32-42

Pinilla, J., Aledo, J.C., Cwiklinski, E., Hyde, R., Taylor, P.M., and Hundal, H.S. (2011) SNAT2 transceptor signalling via mTOR: a role in cell growth and proliferation? Front Biosci (Elite Ed) 3, 1289-99

Prasad, S.M., Czepiel, M., Cetinkaya, C., Smigielska, K., Weli, S.C., Lysdahl, H., Gabrielsen, A., Petersen, K., Ehlers, N., Fink, T., Minger, S.L., and Zachar, V. (2009) Continuous hypoxic culturing maintains activation of Notch and allows long-term propagation of human embryonic stem cells without spontaneous differentiation. Cell Prolif 42(1), 63-74

Price, P.J., Goldsborough, M.D., Tilkins, M.L. International Patent Application WO 98/30679. (1998) Embryonic stem cell serum replacement. International Patent Application WO 98/30679.

Prigione, A., Fauler, B., Lurz, R., Lehrach, H., and Adjaye, J. (2010) The senescencerelated mitochondrial/oxidative stress pathway is repressed in human induced pluripotent stem cells. Stem Cells 28(4), 721-33

Rathjen, J., and Rathjen, P.D. (2003) Lineage specific differentiation of mouse ES cells: formation and differentiation of early primitive ectoderm-like (EPL) cells. Methods Enzymol 365, 3-25

Reubinoff, B.E., Pera, M.F., Fong, C.Y., Trounson, A., and Bongso, A. (2000) Embryonic stem cell lines from human blastocysts: somatic differentiation in vitro. Nat Biotechnol 18(4), 399-404 
Sakkas, D., and Gardner, D.K. (2005) Noninvasive methods to assess embryo quality.

Sancak, Y., Bar-Peled, L., Zoncu, R., Markhard, A.L., Nada, S., and Sabatini, D.M. (2010) Ragulator-Rag complex targets mTORC1 to the lysosomal surface and is necessary for its activation by amino acids. Cell 141(2), 290-303

Shodell, M., and Rubin, H. (1970) Studies on the nature of serum stimulation of proliferation in cell culture. In Vitro 6(1), 66-74

Simon, P. (2003) Q-Gene: processing quantitative real-time RT-PCR data. Bioinformatics 19(11), 1439-40

Stead, E., White, J., Faast, R., Conn, S., Goldstone, S., Rathjen, J., Dhingra, U., Rathjen, P., Walker, D., and Dalton, S. (2002) Pluripotent cell division cycles are driven by ectopic Cdk2, cyclin A/E and E2F activities. Oncogene 21(54), 8320-33

Tan, B.S., Lonic, A., Morris, M.B., Rathjen, P.D., and Rathjen, J. (2011) The amino acid transporter SNAT2 mediates L-proline-induced differentiation of ES cells. Am J Physiol Cell Physiol 300(6), C1270-9

Thompson, J.G., Gardner, D.K., Pugh, P.A., McMillan, W.H., and Tervit, H.R. (1995) Lamb birth weight is affected by culture system utilized during in vitro pre-elongation development of ovine embryos. Biol Reprod 53(6), 1385-91

Thomson, J.A., Itskovitz-Eldor, J., Shapiro, S.S., Waknitz, M.A., Swiergiel, J.J., Marshall, V.S., and Jones, J.M. (1998) Embryonic stem cell lines derived from human blastocysts. Science 282(5391), 1145-7

Varum, S., Rodrigues, A.S., Moura, M.B., Momcilovic, O., Easley, C.A.t., RamalhoSantos, J., Van Houten, B., and Schatten, G. (2011) Energy metabolism in human pluripotent stem cells and their differentiated counterparts. PLoS One 6(6), e20914

Wale, P.L., and Gardner, D.K. (2012) Oxygen regulates amino acid turnover and carbohydrate uptake during the preimplantation period of mouse embryo development. Biol Reprod 87(1), 24, 1-8

Wang, J., Alexander, P., Wu, L., Hammer, R., Cleaver, O., and McKnight, S.L. (2009) Dependence of mouse embryonic stem cells on threonine catabolism. Science 325(5939), 435-9

Warburg, O. (1956) On the origin of cancer cells. Science 123(3191), 309-14

Washington, J.M., Rathjen, J., Felquer, F., Lonic, A., Bettess, M.D., Hamra, N., 811 Semendric, L., Tan, B.S., Lake, J.A., Keough, R.A., Morris, M.B., and Rathjen, P.D. 
812 (2010) L-Proline Induces Differentiation of Es Cells: A Novel Role for an Amino Acid in

813 the Regulation of Pluripotent Cells in Culture. Am J Physiol Cell Physiol

814

815

816

817

818 Yoshida, Y., Takahashi, K., Okita, K., Ichisaka, T., and Yamanaka, S. (2009) Hypoxia

819 enhances the generation of induced pluripotent stem cells. Cell Stem Cell 5(3), 237-41

820

821

822

823

824

825

826

827

828

829

830

831

832

Zachar, V., Prasad, S.M., Weli, S.C., Gabrielsen, A., Petersen, K., Petersen, M.B., and Fink, T. (2010) The effect of human embryonic stem cells (hESCs) long-term normoxic and hypoxic cultures on the maintenance of pluripotency. In Vitro Cell Dev Biol Anim 46(3-4), 276-83

Zhang, J., Khvorostov, I., Hong, J.S., Oktay, Y., Vergnes, L., Nuebel, E., Wahjudi, P.N., Setoguchi, K., Wang, G., Do, A., Jung, H.J., McCaffery, J.M., Kurland, I.J., Reue, K., Lee, W.N., Koehler, C.M., and Teitell, M.A. (2011) UCP2 regulates energy metabolism and differentiation potential of human pluripotent stem cells. EMBO J 30(24), 4860-73 


\section{Figure Legends}

835 Figure 1: Serum induces differentiation from human ES cells. A-C. MEL2 human ES

836 cells were cultured in mTeSR1 for 7 days (A) or mTeSR1 for 72 hours followed by

837 mTeSR1 with 20\% added FCS for 96 hours (B, C). Serum was from Life Technologies

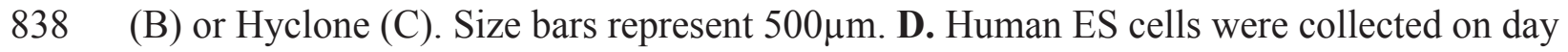

8397 and analysed for the expression of OCT4, NANOG, GATA4 and BRACHYURY by RT-

840 qPCR. $n=8$ independent repeats. Error bars represent SEM. Data was analysed using a

841 two-tailed Student's t-test $* \mathrm{p}<0.05$. E. Human ES cells exposed to Life Technologies

842 FCS for 96 hours were analysed by immunocytochemistry for the presence of NANOG.

843 Nuclei were detected by DAPI. Arrows highlight examples of cells that have lost

844 NANOG expression. F. Human ES cells on day 3 of culture were transferred to

845 mTeSR1+FCS+SB203580 (SB) and cultured for a further 4 days. Cells were collected

846 and analysed for the expression of OCT4, NANOG, SOX2, GATA4 and BRACHYURY by

847 RT-qPCR. Gene expression was normalized to mTeSR1+FCS+DMSO controls. n=3

848 independent repeats. Error bars represent SEM. Data was analysed using a two-tailed

849 Student's t-test \# $\mathrm{p}<0.01$.

$850 \quad$ Figure 2: Exposure to serum changes the use of amino acids in human ES cell

851 cultures. A. Spent medium from the final 24 hours of culture of human ES cells in

852 mTeSR1 for 7 days ( $\square$ ),or mTeSR1 for 72 hours followed by mTeSR1 with 20\% Life

853 Technologies FCS for 96 hours ( $\mathbf{\square})$, was analysed for the presence and concentration of

854 amino acids. Amino acid production (positive values) or consumption (negative values)

855 has been normalised to cell number and is expressed as fmol/cell/hour. $\mathrm{n}=8$ independent 
856 repeats. Error bars represent SEM. Data were analysed using a two-tailed Student's t-test,

$857{ }^{*} \mathrm{p}<0.05 ;{ }^{*} \mathrm{p}<0.01$. B. Total amino acid production, consumption and turnover by cells

858 cultured in medium supplemented with serum.

859 Figure 3: Differentiation of human ES cells with BMP4 does not result in changes in

860 amino acid usage. A,B. Human ES cells were cultured in mTeSR1 for 5 days (A) or

861 mTeSR1 for 72 hours followed by 48 hours in mTeSR1 with $30 \mathrm{ng} / \mathrm{mL}$ BMP4 (B). Size

862 bars represent $500 \mu \mathrm{m}$. C. Human ES cells were cultured in mTeSR1 for 7 days or

863 mTeSR1 for 72 hours followed by 96 hours in mTeSR1 with $30 \mathrm{ng} / \mathrm{mL}$ BMP4. Spent

864 medium from the final 24 hours of culture was analysed for the presence and

865 concentration of amino acids. Amino acid production (positive values) or consumption

866 (negative values) has been normalised to cell number and is expressed as fmol/cell/hour.

$867 \mathrm{n}=6$ independent repeats. Error bars represent SEM. Data were analysed statistically

868 using a two-tailed Student's t-test; $* \mathrm{p}<0.05$. D. Total amino acid production,

869 consumption and turnover by cells cultured in medium supplemented with BMP4.

870 Figure 4: The addition of 20\% Knockout ${ }^{\mathrm{TM}}$ SR does not induce detectable

871 differentiation in human ES cells cultures. A,B. Human ES cells were cultured in

872 mTeSR1 for 7 days (A) or mTeSR1 for 72 hours followed by 96 hours in mTeSR 1 with

$87320 \%$ Knockout $^{\mathrm{TM}}$ SR (B). Size bars represent $500 \mu \mathrm{m}$. C. Cells were collected on day 7

874 and analysed for the expression of OCT4, NANOG, GATA4 and BRACHYURY by RT-

875 qPCR. $n=8$ independent repeats. Error bars represent SEM. Data was analysed using a

876 two-tailed Student's t-test; no differences were detected. 
877 Figure 5: Exposure to Knockout ${ }^{\mathrm{TM}}$ SR changes amino acid metabolism in human ES

878 cells. A. Spent medium from the final 24 hours of culture of human ES cells in mTeSR1

879 for 7 days ( $\square$ ), or mTeSR1 for 72 hours followed by mTeSR1 with $20 \%$ Knockout ${ }^{\text {TM }}$ SR

880 for 96 hours ( $\mathbf{\square})$, was analysed for the presence and concentration of amino acids. Amino

881 acid production (positive values) or consumption (negative values) has been normalised

882 to cell number and is expressed as fmol/cell/hour. $n=12$ (6 independent repeats with

883 duplicate wells for each experiment). Error bars represent SEM. Data were analysed

884 using a two-tailed Student's t-test, $*_{\mathrm{p}}<0.05 ; * * \mathrm{p}<0.01$. B. Total amino acid production,

885 consumption and turnover by cells cultured in medium supplemented with Knockout ${ }^{\mathrm{TM}}$

886 SR. 


\begin{tabular}{|c|c|c|c|}
\hline & $\begin{array}{l}\text { Glucose } \\
\text { consumption } \\
\text { (fmol/cell/hour) }\end{array}$ & $\begin{array}{l}\text { Lactate } \\
\text { Production } \\
\text { (fmol/cell/hour) }\end{array}$ & \%Glycolysis \\
\hline mTeSR & $160 \pm 9$ & $162 \pm 12$ & $50.5 \pm 2.1$ \\
\hline mTeSR + FCS $; 24$ hours $^{\text {b }}$ & $181 \pm 24$ & $187 \pm 24$ & $52.3 \pm 3.3$ \\
\hline mTeSR + FCS ${ }^{\mathrm{a}} ; 96$ hours & $357 \pm 38 * *$ & $359 \pm 40 * *$ & $50.5 \pm 3.4$ \\
\hline mTeSR & $162 \pm 12$ & $171 \pm 14$ & $53.7 \pm 1.4$ \\
\hline mTeSR + BMP4 $4^{\mathrm{c}} ; 96$ hours & $163 \pm 10$ & $182 \pm 14$ & $55.1 \pm 3.3$ \\
\hline mTeSR & $171 \pm 20$ & $179 \pm 11$ & $52.1 \pm 1.6$ \\
\hline mTeSR + KOSR ${ }^{\mathrm{d}}$; 96 hours & $242 \pm 16^{* *}$ & $251 \pm 15^{* *}$ & $52.1 \pm 2.5$ \\
\hline
\end{tabular}

Table 1. Carbohydrate use by human ES cells cultured in mTeSR1 with and without supplementation. ${ }^{a} 20 \%$ FCS from Life Technologies. ${ }^{b}$ All measurements were made on medium taken after the final 24 hours of culture; time in the conditions indicates the length of exposure of the cells to the supplement. ${ }^{\mathrm{c}} \mathrm{BMP} 4$ at 30 ng/ml. ${ }^{\mathrm{d}}$ 20\% KOSR from Life Technologies. 
$\%$ cells in mitosis

$$
\text { +/- s.e.m. }
$$

$p$-value

\begin{tabular}{lll}
\hline $\mathbf{m T e S R}$ & $3.6 \pm .3$ & \\
$\mathbf{m T e S R}^{+ \text {FCS }^{\mathrm{a}}}$ & $4.3 \pm .5$ & .26 \\
$\mathbf{m T e S R}^{+ \text {KOSR }^{\mathrm{b}}}$ & $3.0 \pm .5$ & .27 \\
\hline
\end{tabular}

Table 2: Proliferation of human ES cells, shown as the \% of cells positive for phosphorylated histone H3. ${ }^{\mathrm{a}} 20 \%$ FCS from Life Technologies. ${ }^{\mathrm{b}} 20 \%$ Knockout Serum Replacer from Life Technologies. $P$-value determined by Student's t-test when compared to cells cultured in mTeSR. Analysis was of 20 fields from two independent replicates. 


\begin{tabular}{|c|c|c|c|}
\hline & Average cell number & $p$-value & $\begin{array}{c}\% \\
\text { mTeSR }\end{array}$ \\
\hline $\begin{array}{l}\text { mTeSR } \\
\text { mTeSR + FCS }\end{array}$ & $\begin{array}{l}1.92 \times 10^{6} \pm 1.43 \times 10^{5} \\
9.60 \times 10^{5} \pm 1.83 \times 10^{5}\end{array}$ & $2.00 \times 10^{-3}$ & $49.8 \pm 8.1$ \\
\hline 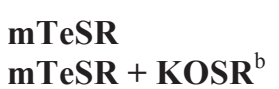 & $\begin{array}{l}2.09 \times 10^{6} \pm 8.90 \times 10^{4} \\
1.24 \times 10^{6} \pm 8.40 \times 10^{4}\end{array}$ & $9.57 \times 10^{-12}$ & $61.0 \pm 2.5$ \\
\hline
\end{tabular}

Table 3: Cell numbers after 4 days of supplement addition. ${ }^{a} 20 \%$ FCS from Life Technologies. ${ }^{b} 20 \%$ Knockout Serum Replacer from Life Technologies. Statistical comparison of raw cell numbers was performed using a paired Student's t-test, and of cell numbers relative to mTeSR with an unpaired Student's t-test. 

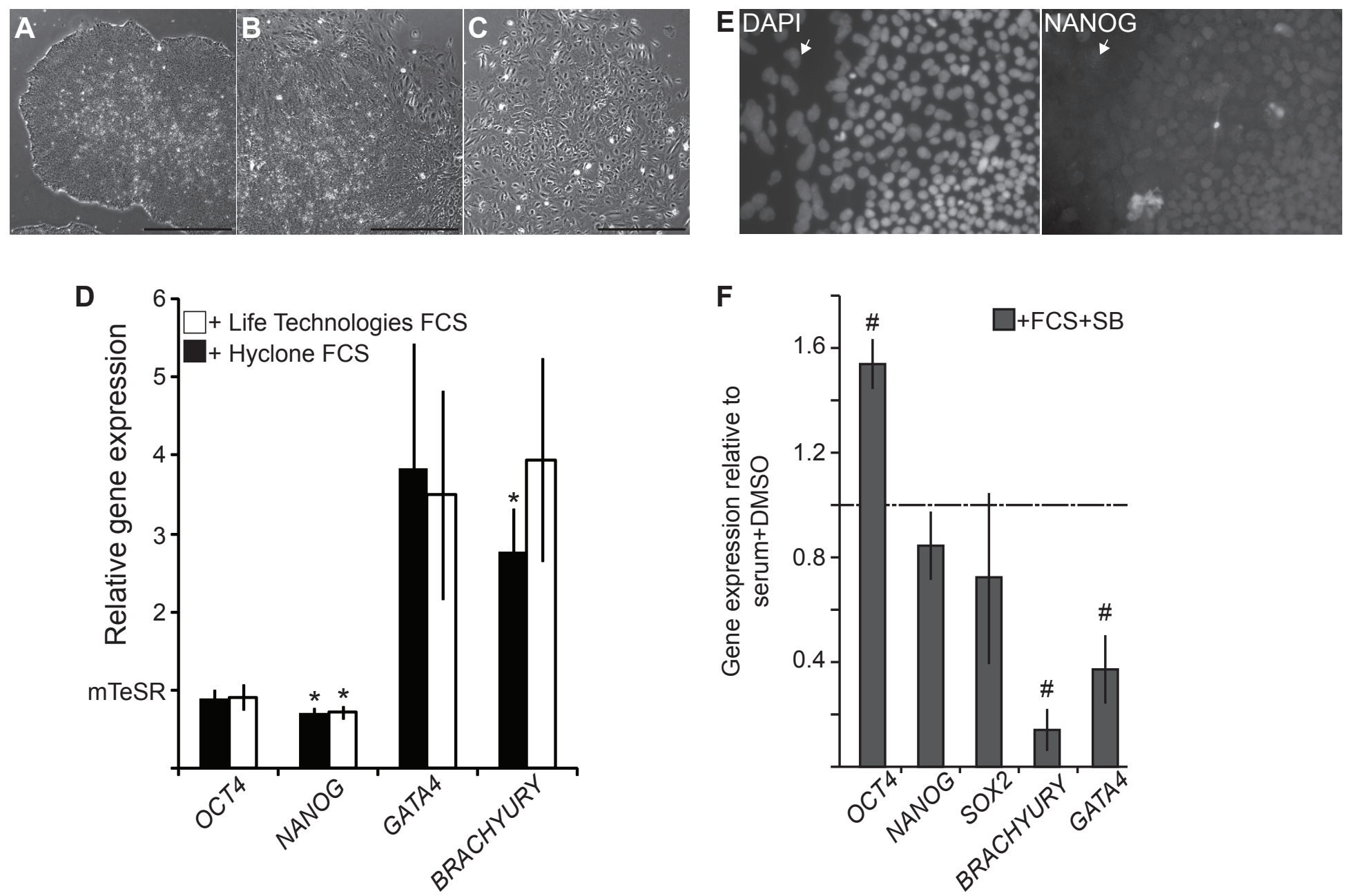

Figure 1 


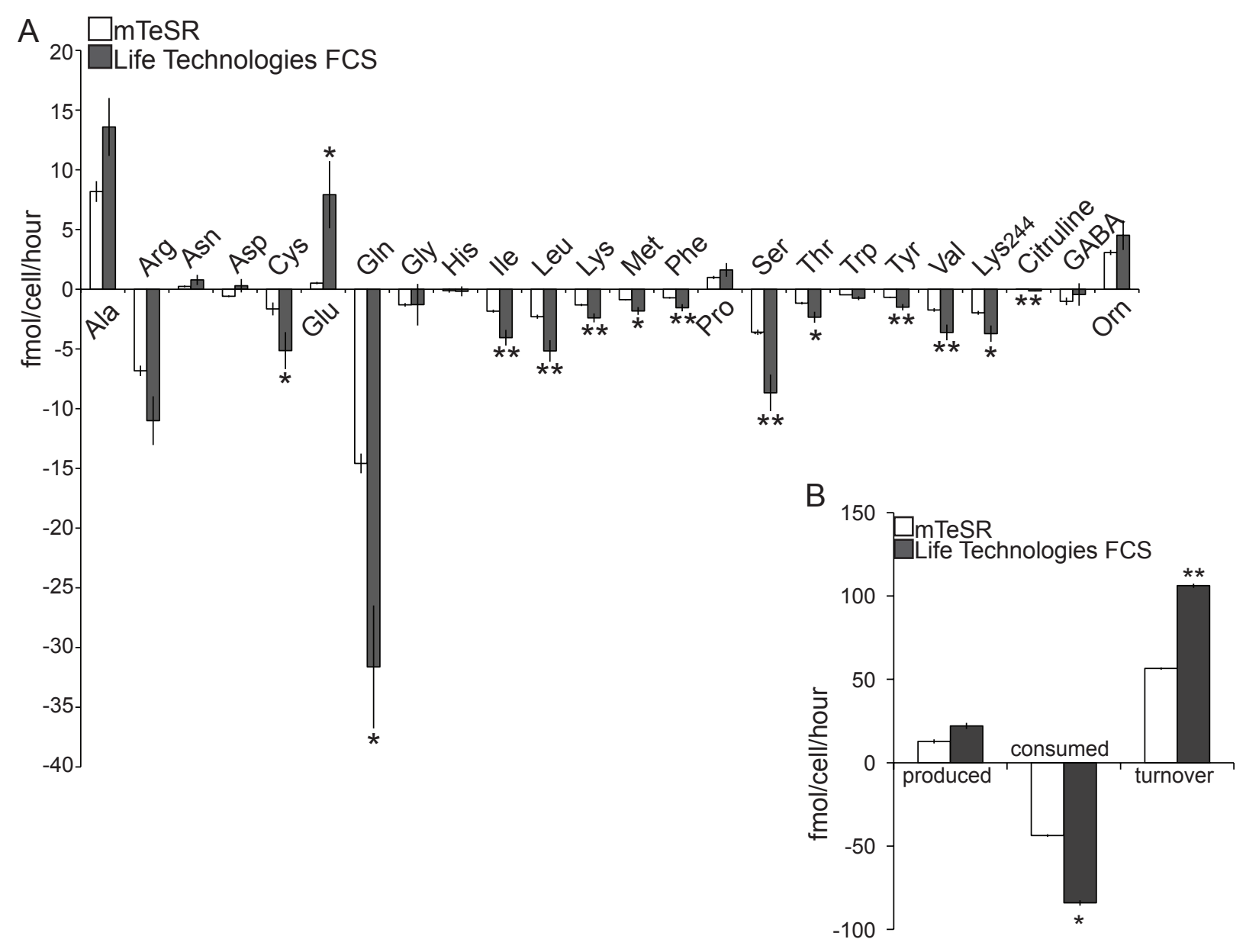

Figure 2_Rathjen et al., 

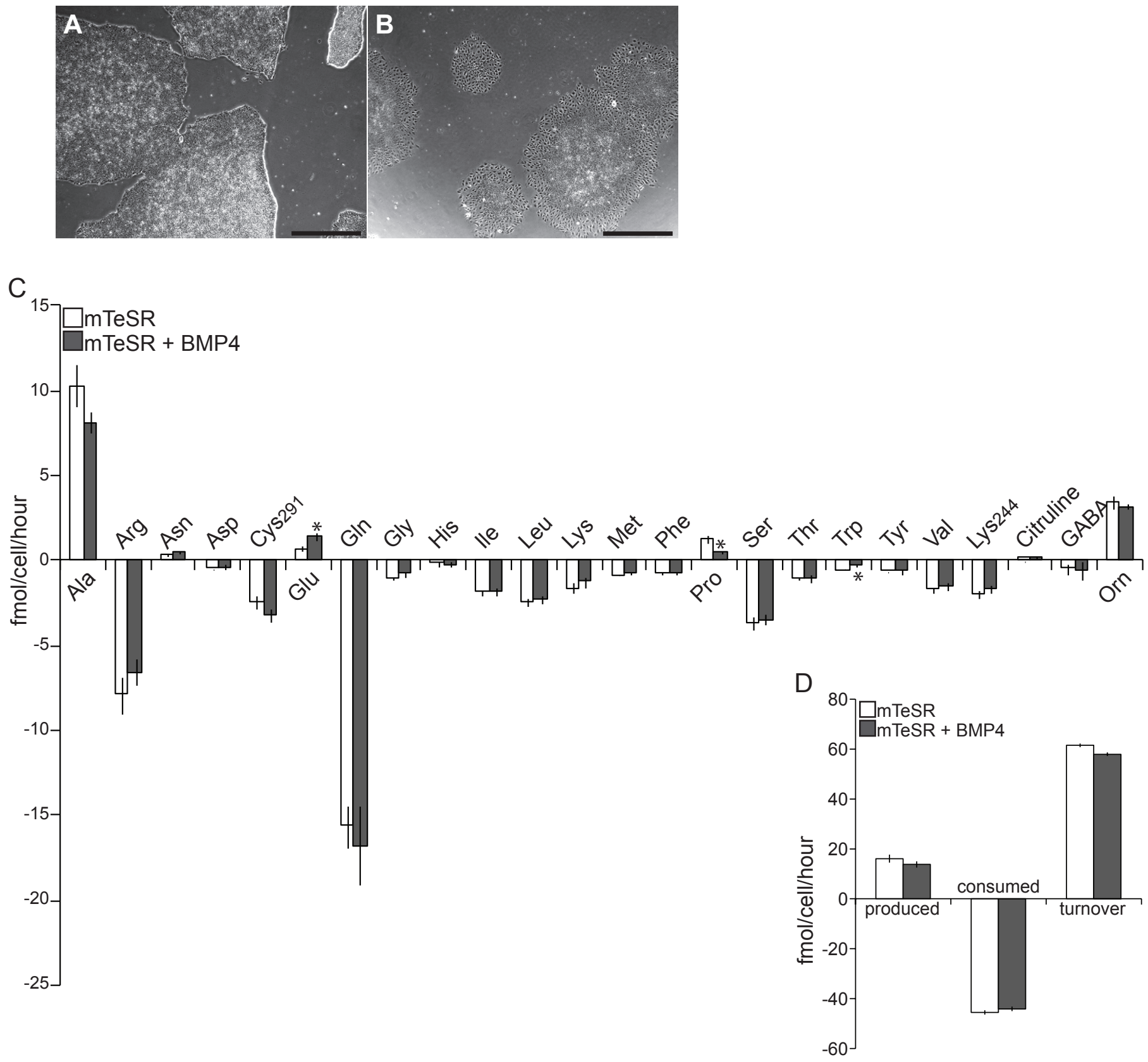

Figure 3_Rathjen et al. 

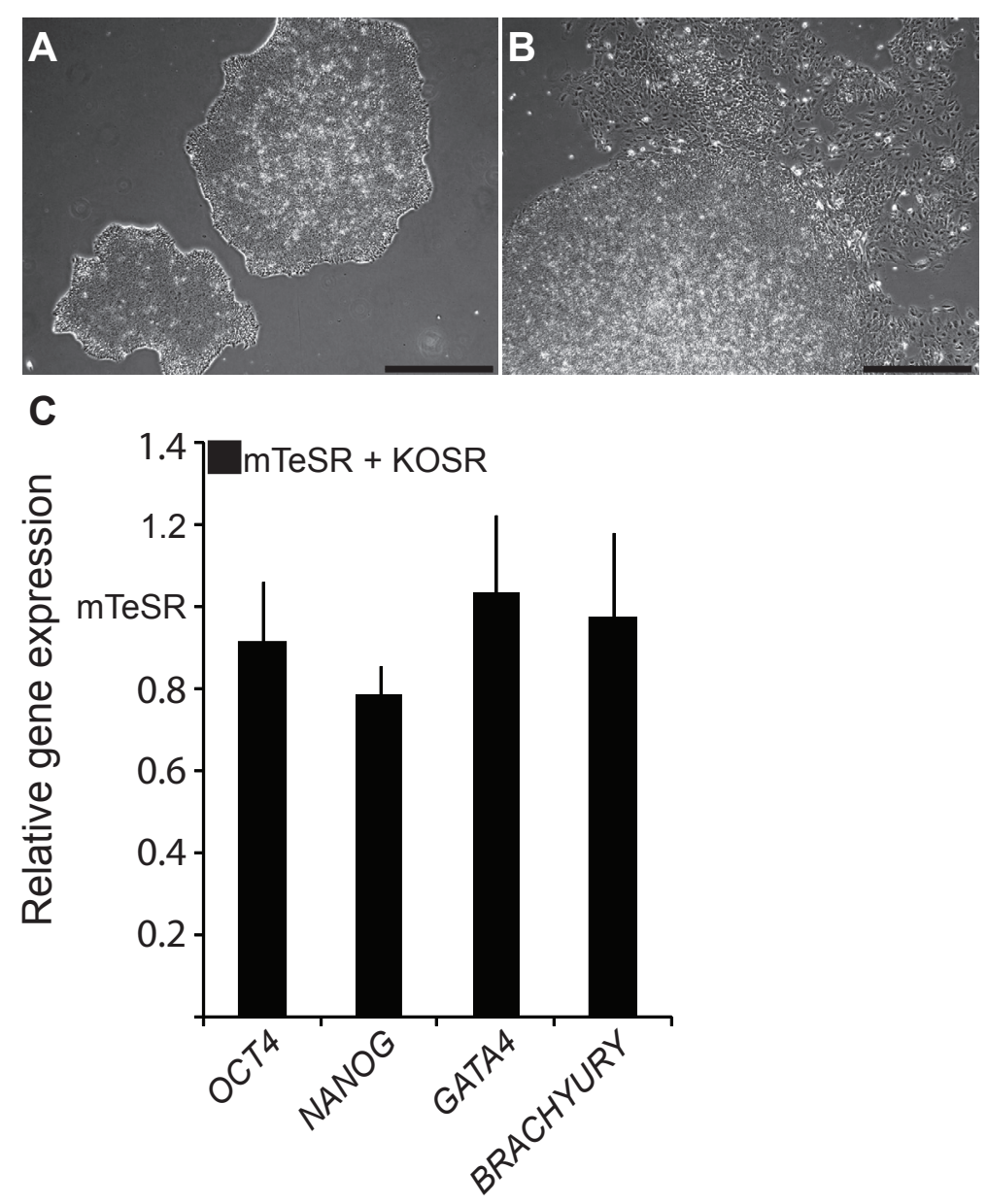

Figure 4 
A

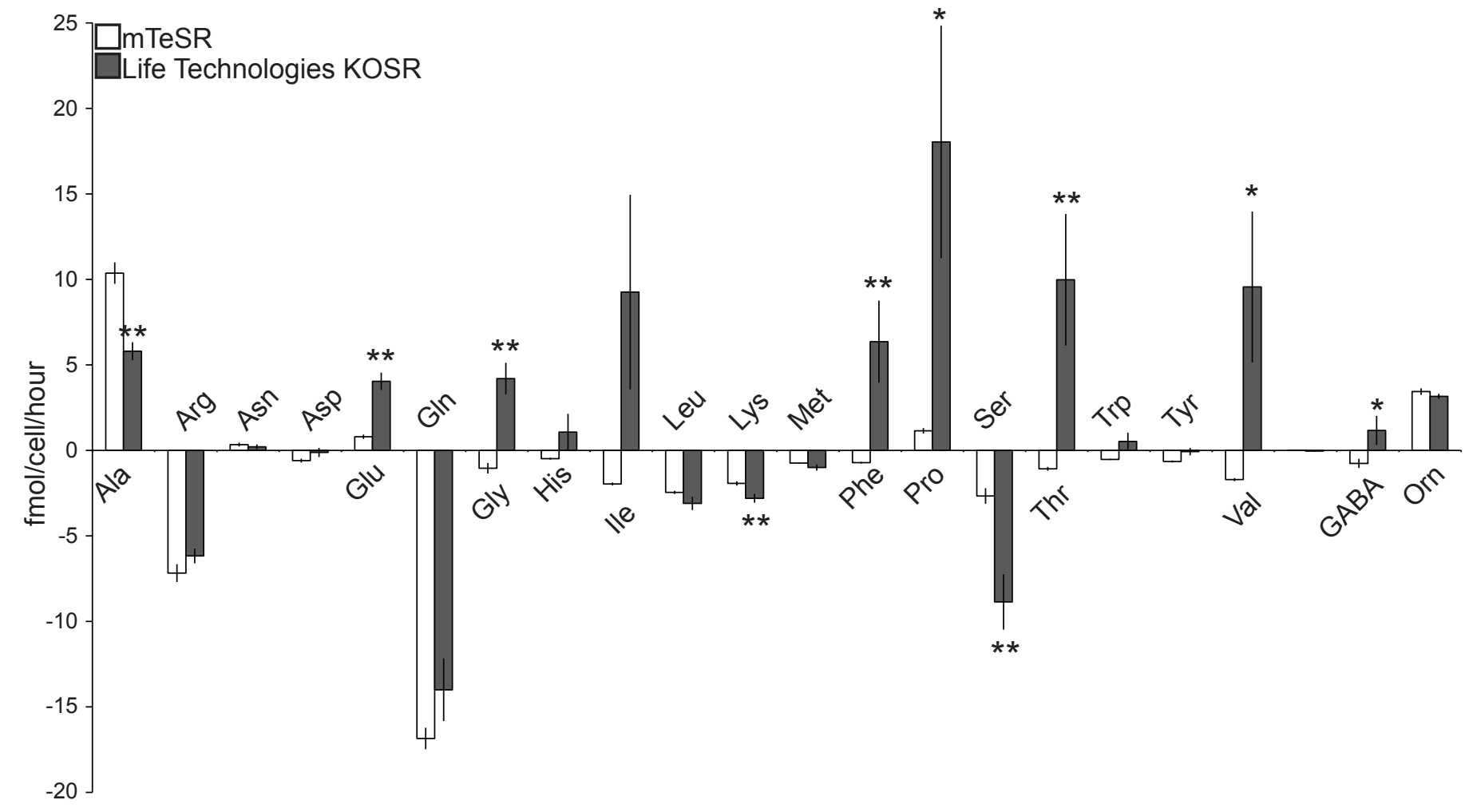

B

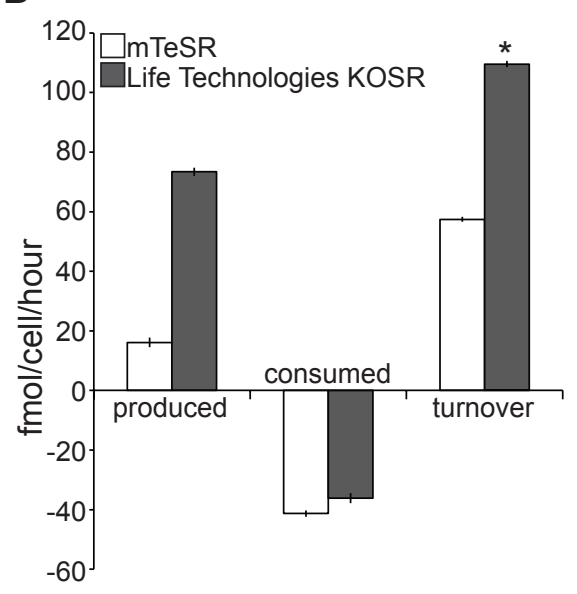

Figure 5_Rathjen 


\begin{tabular}{lll}
\hline Gene & $\begin{array}{l}\text { Forward primer } \\
\mathbf{5}^{\prime}-\mathbf{3}\end{array}$ & $\begin{array}{l}\text { Reverse primer } \\
\mathbf{5}^{\prime}-\mathbf{3}\end{array}$ \\
\hline B-ACTIN & CGCACCACTGGCATTGTC & TCCTCCTTGATGTCACGCAC \\
BRACHYURY & GTGCTGTCCCAGGTGGCTTACAGATG & CCTTAACAGCTCAACTCTAACTACTTG \\
GATA4 & CTAGACCGTGGGTTTGCAT & TGGGTTAAGTGCCCTGTAG \\
NANOG & CAAAGGCAAACAACCCACTT & TCTGCTGGAGGCTGAGGT \\
OCT4 & AGCGAACCAGTATCGAGAAC & TTACAGAACCACACTCGCAC \\
SOX2 & ATGCACCGCTACGACGTGA & CTTTTGCACCCCTCCCATTT \\
\hline
\end{tabular}

Table S1: Primer sequences used for qPCR analysis of gene expression. 


\begin{tabular}{lllll}
\hline & $\begin{array}{l}\text { Expected glucose } \\
\text { concentration } \\
(\mathrm{mM})\end{array}$ & $\begin{array}{l}\text { Measured glucose } \\
\text { concentration } \\
(\mathrm{mM})\end{array}$ & $\begin{array}{l}\text { Expected lactate } \\
\text { concentration } \\
(\mathrm{mM})\end{array}$ & $\begin{array}{l}\text { Measured lactate } \\
\text { concentration } \\
(\mathrm{mM})\end{array}$ \\
\hline mTeSR & 13.7 & $15.2 \pm .4$ & 0 & 0 \\
mTeSR + FCS & & $13.4 \pm .5$ & & $2.4 \pm .1$ \\
mTeSR + BMP4 & 13.7 & $14.5 \pm .3$ & 0 & 0 \\
mTeSR + KOSR & & $13.7 \pm .4$ & & 0 \\
\hline
\end{tabular}

Table S2: Measured concentrations of glucose and lactate in control media. 


\begin{tabular}{llll}
\hline & $\begin{array}{l}\text { mTeSR } \\
\text { formulation } \\
(\mu \mathrm{M})\end{array}$ & $\begin{array}{l}\text { mTeSR } \\
(\mu \mathrm{M})\end{array}$ & $\begin{array}{l}\text { mTeSR + FCS } \\
(\mu \mathrm{M})\end{array}$ \\
\hline Ala & 137 & $158 \pm 3.54$ & $326 \pm 4.6^{* *}$ \\
Arg & 548 & $459 \pm 8.5$ & $328 \pm 5.6$ \\
Asn & 137 & $129 \pm 2.1$ & $103 \pm 1.5$ \\
Asp & 137 & $157 \pm 3.4$ & $144 \pm 2.8$ \\
Glu & 137 & $157 \pm 2.9$ & $301 \pm 3.6^{* *}$ \\
Gln & 2940 & $2362 \pm 38.1$ & $1973 \pm 38$ \\
Gly & 294 & $269 \pm 7.9$ & $336 \pm 10.7^{* *}$ \\
His & 118 & $151 \pm 1.9$ & $145 \pm 2.5$ \\
Ile & 326 & $318 \pm 6.1$ & $291 \pm 3.5$ \\
Leu & 354 & $352 \pm 7.1$ & $333 \pm 3.8$ \\
Lys & 391 & $358 \pm 5.5$ & $331 \pm 3.2$ \\
Met & 90.6 & $89 \pm 1.9$ & $76 \pm 1.2$ \\
Phe & 169 & $187 \pm 3.5$ & $182 \pm 2.1$ \\
Pro & 216 & $233 \pm 2.8$ & $237 \pm 2.1$ \\
Ser & 294 & $304 \pm 8.9$ & $300 \pm 8.1$ \\
Thr & 352 & $343 \pm 6.4$ & $301 \pm 3.2$ \\
Trp & 34.6 & $68 \pm 1.2$ & $71 \pm 1.3$ \\
Tyr & 168 & $174 \pm 3.1$ & $160 \pm 1.7$ \\
Val & 355 & $355 \pm 6.4$ & $355 \pm 3.8$ \\
\hline
\end{tabular}

Table S3: Measured concentrations of amino acids in $\mathrm{mTeSR}$ and $\mathrm{mTeSR}$ supplemented with $20 \%$ Life Technologies FCS, compared to the expected concentrations from the published formulation of the medium ${ }^{18}$. ** $\mathrm{p}<0.01$; significance was tested for those amino acids showing an increased concentration in serum containing medium. 


\begin{tabular}{lllll}
\hline & $\begin{array}{l}\text { mTeSR } \\
\text { formulation } \\
(\boldsymbol{\mu M})\end{array}$ & $\begin{array}{l}\text { mTeSR } \\
(\boldsymbol{\mu M})\end{array}$ & $\begin{array}{l}\text { mTeSR }+ \\
\text { KOSR } \\
\text { formulation } \\
(\boldsymbol{\mu M})\end{array}$ & $\begin{array}{l}\text { mTeSR + KOSR } \\
(\boldsymbol{\mu M})\end{array}$ \\
\hline Ala & 137 & $144 \pm 2.5$ & 109.6 & $123 \pm 4.9$ \\
Arg & 548 & $581 \pm 4.9$ & 438.4 & $463 \pm 16.1$ \\
Asn & 137 & $142 \pm 2.2$ & 109.6 & $113 \pm 2.7$ \\
Asp & 137 & $139 \pm 8.8$ & 109.6 & $106 \pm 4$ \\
Glu & 137 & $138 \pm 6.2$ & 109.6 & $105 \pm 6$ \\
Gln & 2940 & $2614 \pm 29.5$ & 2352 & $2065 \pm 46.5$ \\
Gly & 294 & $296 \pm 4.5$ & 1176.4 & $621 \pm 19.1$ \\
His & 118 & $116 \pm 7.6$ & 1667 & $925 \pm 36.3$ \\
Ile & 326 & $332 \pm 6.4$ & 6512 & $4957 \pm 118.8$ \\
Leu & 354 & $358 \pm 6.8$ & 283.2 & $369 \pm 9.4$ \\
Lys & 391 & $393 \pm 10.7$ & 312.8 & $308 \pm 8.3$ \\
Met & 90.6 & $81.6 \pm 4.3$ & 465.68 & $172 \pm 4.4$ \\
Phe & 169 & $188 \pm 4.1$ & 2847.2 & $2129 \pm 55.6$ \\
Pro & 216 & $242 \pm 5.9$ & 711.2 & $6445 \pm 144.5$ \\
Ser & 294 & $281 \pm 4.7$ & 2290.6 & $1635 \pm 46.5$ \\
Thr & 352 & $353 \pm 9$ & 5038.2 & $3452 \pm 82$ \\
Trp & 34.6 & $47 \pm 2.9$ & 812 & $455 \pm 13$ \\
Tyr & 168 & $226 \pm 4.9$ & 752 & $225 \pm 4.9$ \\
Val & 355 & $370 \pm 7.4$ & 5450 & $3977 \pm 92.6$ \\
\hline
\end{tabular}

Table S4: Measured concentrations of amino acids in mTeSR and mTeSR supplemented with $20 \%$ Life Technologies KOSR, compared to the expected concentrations from the published formulation of $\mathrm{mTeSR}^{18}$ and $\mathrm{mTeSR}+$ KOSR. Expected concentrations for amino acids in KOSR were taken from the preferred embodiment of the supplement ${ }^{20}$. 


\begin{tabular}{lcccc}
\hline & $\begin{array}{c}\text { \% cells in mitosis } \\
\pm \text { s.e.m. }\end{array}$ & $\boldsymbol{p}$-value & $\begin{array}{c}\text { Fluorescent } \\
\text { intensity } \\
\text { (relative units) } \\
\pm \text { s.e.m. }\end{array}$ & $p$-value \\
\hline mTeSR & $3.6 \pm .3$ & & $2.95 \pm .3$ & .65 \\
mTeSR + F12 & $3.6 \pm .3$ & .86 & $2.76 \pm .2$ & \\
\hline
\end{tabular}

Table S5: Proliferation of human ES cells, shown as the \% of cells positive for phosphorylated histone H3, in medium conditions used, and final live cell density, estimated be Alamar Blue staining, shown as fluorescent intensity. $P$-value determined by Student's t-test when compared to cells cultured in mTeSR. Analysis was of 20 fields from two independent replicates (proliferation rate) and 6 replicate wells (final live cell density). 


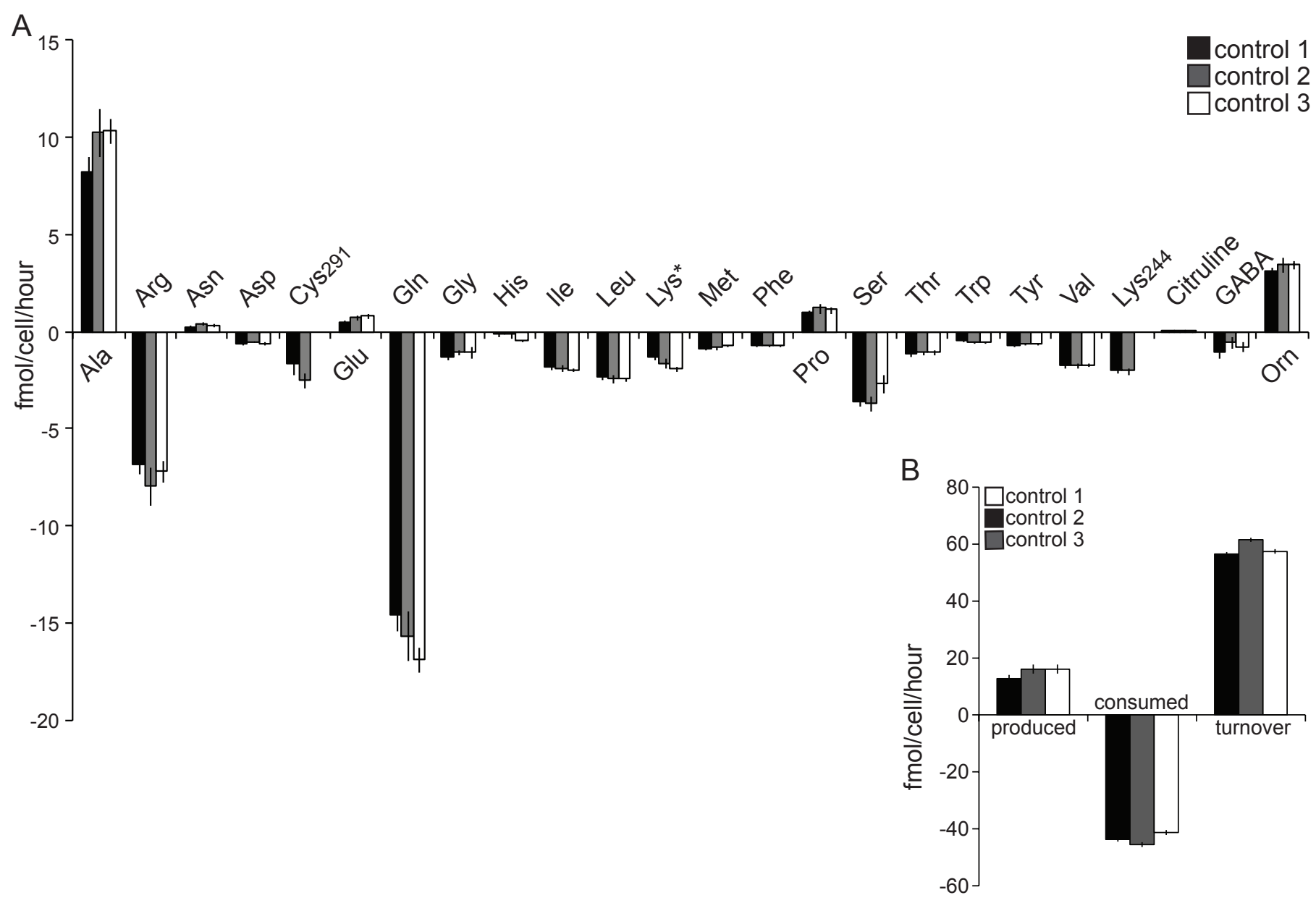

Figure S2: Comparison of amino acid use in human ES cell cultures across experimental procedures.

A. Spent medium from the final 24 hours of culture of human ES cells in mTeSR 1 for 7 days was analysed for the presence and concentration of amino acids. Amino acid production or consumption was normalised to cell number and is expressed as fmol/cell/hour. $n=8$ (Control 1); $n=6$ (Control 2); $n=12$ (Control 3). Error bars represent SEM. Data were analysed using ANOVA, ${ }^{*} \mathrm{p}<0.05$. B. Total amino acid production, consumption and turnover by cells cultured in mTeSR1.

\section{Supplementary figure 1_Rathjen et al.}



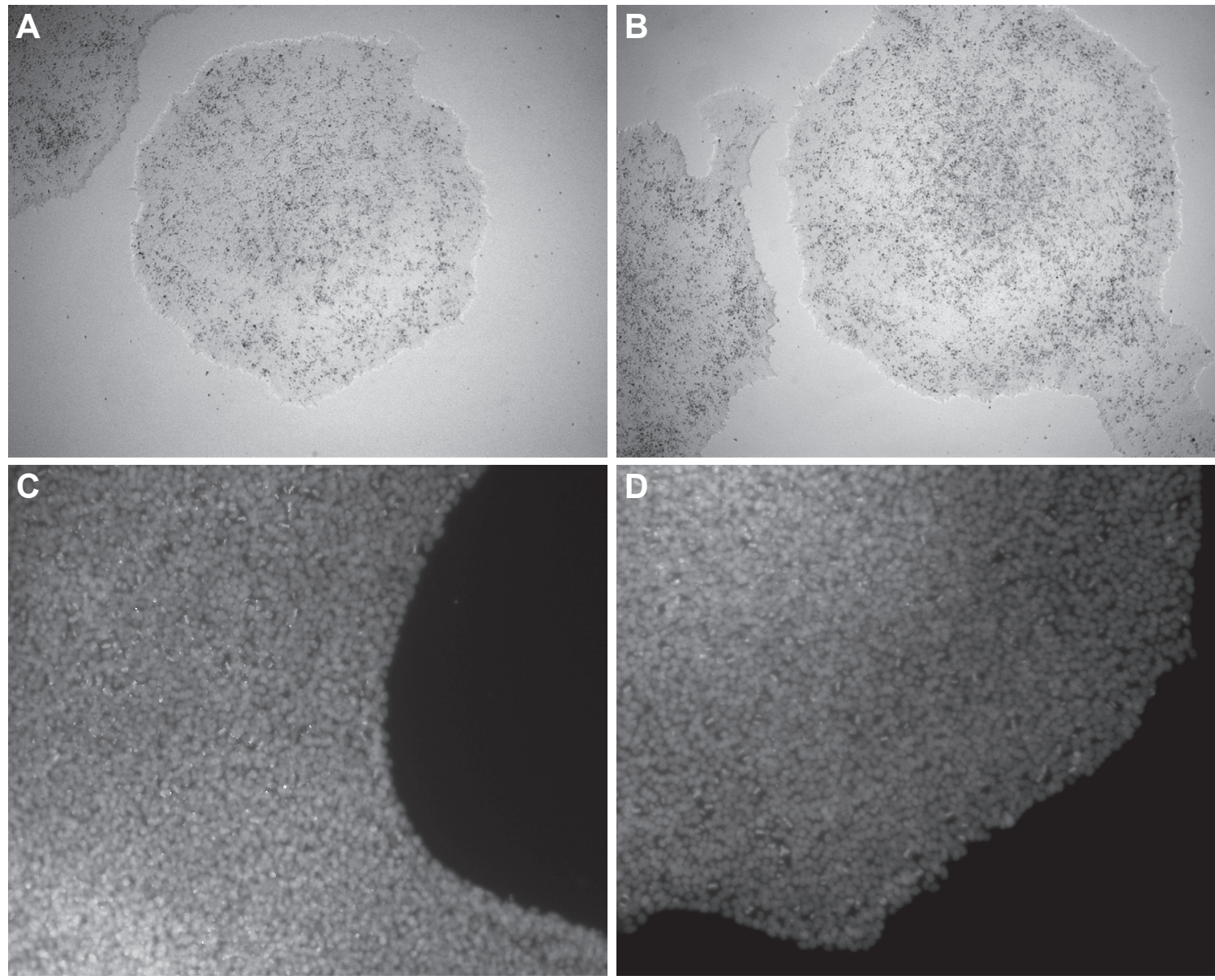

Supplementary Figure 2: Morphology of human ES cells cultured in mTeSR1 supplemented with 20\% Hams F12 medium. Human ES cells were cultured for 3 days in mTeSR1 before being changed into mTeSR1 (A,C) or mTeSR1 supplemented with 20\% Hams F12 (B,D) and maintained for a further 4 days. Images of colony morphology were captured in phase contrast at $4 \mathrm{x}$ magnification $(A, B)$ or with fluorescence microscopy after staining for DNA with DAPI (C,D; 20 x magnification). $\mathrm{n}=3$; representative images are shown.

Supplementary figure 2_Rathjen et al. 